\title{
Gölle, Kisgyalán, Fonó és Büssü települések kulturális élete a 20. században
}

\author{
LANSZKINÉ SZÉLES GABRIELLA
}

Kaposvári Egyetem Agrár- és Környezettudományi Kar, H-7401 Kaposvár, Pf. 16., e-mail: lanszkine.gabriella@ke.hu

\begin{abstract}
LANSZKINÉ SzÉLES, G.: Cultural life of villages Gölle, Kisgyalán, Fonó and Büssü (Hungary) in twentieth century.

Abstract: This study focuses on evaluating half a century of cultural events, especially the theatricals of Outer-Somogy villages, namely Gölle, Kisgyalán, Fonó and Büssü. Photographic materials, play-books, reminiscences were collected and compared to the historical background and other villages in Somogy county.
\end{abstract}

Keywords: cultural life, materials play-books, theatricals of Outer-Somogy villages, photographic, play

Gölle, Fonó, Büssü, Kisgyalán, ${ }^{1}$ községekben a színdarabokról készült fényképeket évekkel ezelőtt kezdtem el gyüjteni. A színre vitt színművek iránt is fokozódott az érdeklődésem, amikor többszőr „akadtak” a kezembe 1930-1940-es évek között kiadott színdarabok szövegkönyvei, amelyeket megjelenésüket követő években már színre is vittek falvainkban. Ezek a megsárgult füzetecskék majd egy emberöltő távlatán túl is nagy becsben vannak tartva (1-2. ábra). A ma visszaemlékezők ragaszkodnak a szerepkönyveikhez, mivel az emlékek élénken élnek a szereptanulástól a színpad előkészítésén túl a színre vitelig. A szereposztás pl. olvasható Illyésné Ferenczy Emma: A nánai bíró lánya (1938) címú szerepkönyvben, ami újra a figyelem központjába került. Többen újra olvasták, amikor kölcsönkértem a nyomtatott füzetecskét szülőfalumban, Kisgyalánban. Így újra elevenedett a történet fél évszázad után is.

D. Kelemen Alán:² Szűz Mária Koronája című színmű szövegkönyvét (1. ábra) kalandos úton őrizte meg az utókor számára Kalmár Sándor (1919-1998) és Bóna Lászlóné (Széles Rózsa 1930). Kalmár Sándor néptanító Göllében, Kisgyalánban, Fonóban egyaránt tanított. Szerepe feleségével Angyal Magdolnával együtt Fonó és Kisgyalán életében meghatározó jelentőségü, a tanításon túl a színjátszást mindkét községben szívügyüknek tekintették.

„Kalmár Sándor oklevéllel a kezében szülőfalujában, Kisgyalánban szeretett volna tanítani. Itt azonban az állás be volt töltve. Németladon, mivel az ottani tanító bevonult katonának szükség volt helyettesre.

1 Ezek a külső - somogyi Kapos menti falvak egymás szomszédságában 3-4 km távolságban találhatóak.

2 Kelemen Alán Gábor, OFM (Nagykáta, Pest vm., 1909. szept. 26. Andocs, 1986. nov. 6.): szerzetes. - 1928. VIII. 16: lépett a Szüz Máriáról nev. Ferences rendbe, 1932. VIII. 18: ünn. fogadalmat tett, 1936. VII. 12: pappá szentelték. Andocson, 1942: Esztergomban élt, 1945-50: Felsősegesden plébános. - M: Szüz Mária koronája. Színmü. Andocs, 1938. D.D. Kelemen - Magyar Katolikus Lexikonlexikon.katolikus.hu > $\mathrm{K}$
Az első tanítási nap 1939. szeptember 1-je volt, ami örökre emlékezetes maradt az ifjú tanító úr számára, ezen a napon kezdődött a II. világháború. (...) 1941ben behívták katonának. Ekkor hirdették meg Fonóban a kántortanítói állást. $A$ jelentkezők között volt Kalmár Sándor is. Az iskolaszék őt látta legalkalmasabbnak a kántortanítói feladatok ellátására. A háborús helyzetre való tekintettel őt bármikor újból behívhatják és kivihetik a frontra. Ezért vállalnia kellett, hogy gondoskodik egy helyettes tanerőről. Júniusban elutazott Pécsre, és a zárda főnöknőjével vette fel a kapcsolatot, hogy szüksége lenne egy most végző tanítónőre, aki falun munkát vállalna, és szükség esetén helyettesítene is. $A z$ ajánlatra a végzős osztály egyik legjobb tanulója Angyal Magdolna jelentkezett, és 10 nappal a képesítői vizsgái után 1942. június 29-én érkezett Fonóba. Még szinte meg sem száradt a tinta oklevelén, mikor egyetlen napi pihenés nélkül önként elkezdte tanítani a gyerekeket. Közben a munka összekötő szálai erős érzelmi kapocscsá mélyültek, s a következő nyáron megtartották eljegyzésüket. 1944. augusztus 5-én hívták be újból Kalmár Sándort a hadseregbe. (...) 42 évi és 80 napi tanítás után 1980 szeptemberében ment nyugdíjba Sándor bácsi. Ekkor, ahogy ő mondta: a munkaviszonya változott meg, a munkához való viszonya nem. Tagja volt a megyei Pedagógus Férfikórusnak, a Kisgyaláni Férfikarnak. Ő volt a kisgyaláni könyvtár vezetője is." ${ }^{3}$ Hetvenöt év telt el Kalmár Sándor fonói kántortanítóvá választása óta. Adatközlőőim emlékeznek rá, hogy a kántori feladatkör betöltéséhez szükséges „vizsgafeladatnak” mit választott a leendő kántortanító. A fonóiak a gyalániak kérdezősködésére - természetesen kíváncsiak voltak tanult falubelijükre - elmondták az ima címét 1941-ben. 2016-ban érdeklődésemre Bóna Lászlóné (1930) egy percnyi gondolkodás nélkül elénekelte a nehéz dallamú imádságot, amely így hangzik: „Ha éltem útjain veszély közelg felém, Ó Édes Jézus Szent Szíve hozzád sóhajtok én, Viharnak közepén nem küzdök egyedül, az élet tengerén sajkám el nem merül."

Dömötör Tekla is a tanítók összetett feladatára tér ki: „Sok faluban, ahol jártam, emlegettek például már 20-30 éve meghalt, vagy a faluból régen távozott tanítókat is, akiknek annak idején gondja volt a kultúrmunkára: akik önfeláldozó szeretettel, idejüket nem kímélve darabokat rendeztek, foglalkoztak a fiatalokkal." ${ }^{4}$ A tanítói feladatkör összetettebb volt, a kántori feladatkörön túl a tanórákon túli népművelői

3 Virág É. 1988:

4 Dömötör T. 1960: 25. 


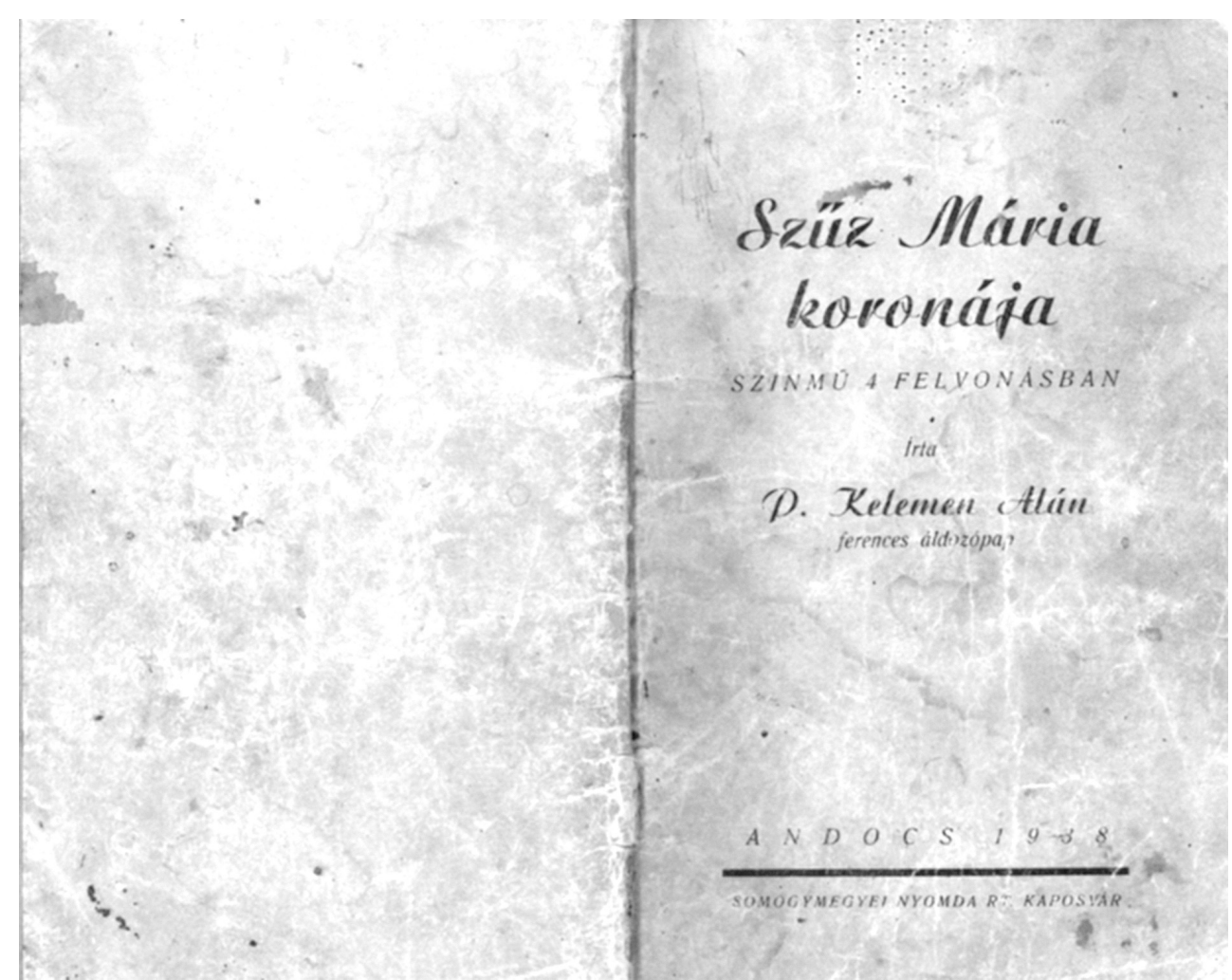

1. ábra. D. Kelemen Alán: Szüz Mária Koronája szövegkönyve (1938)

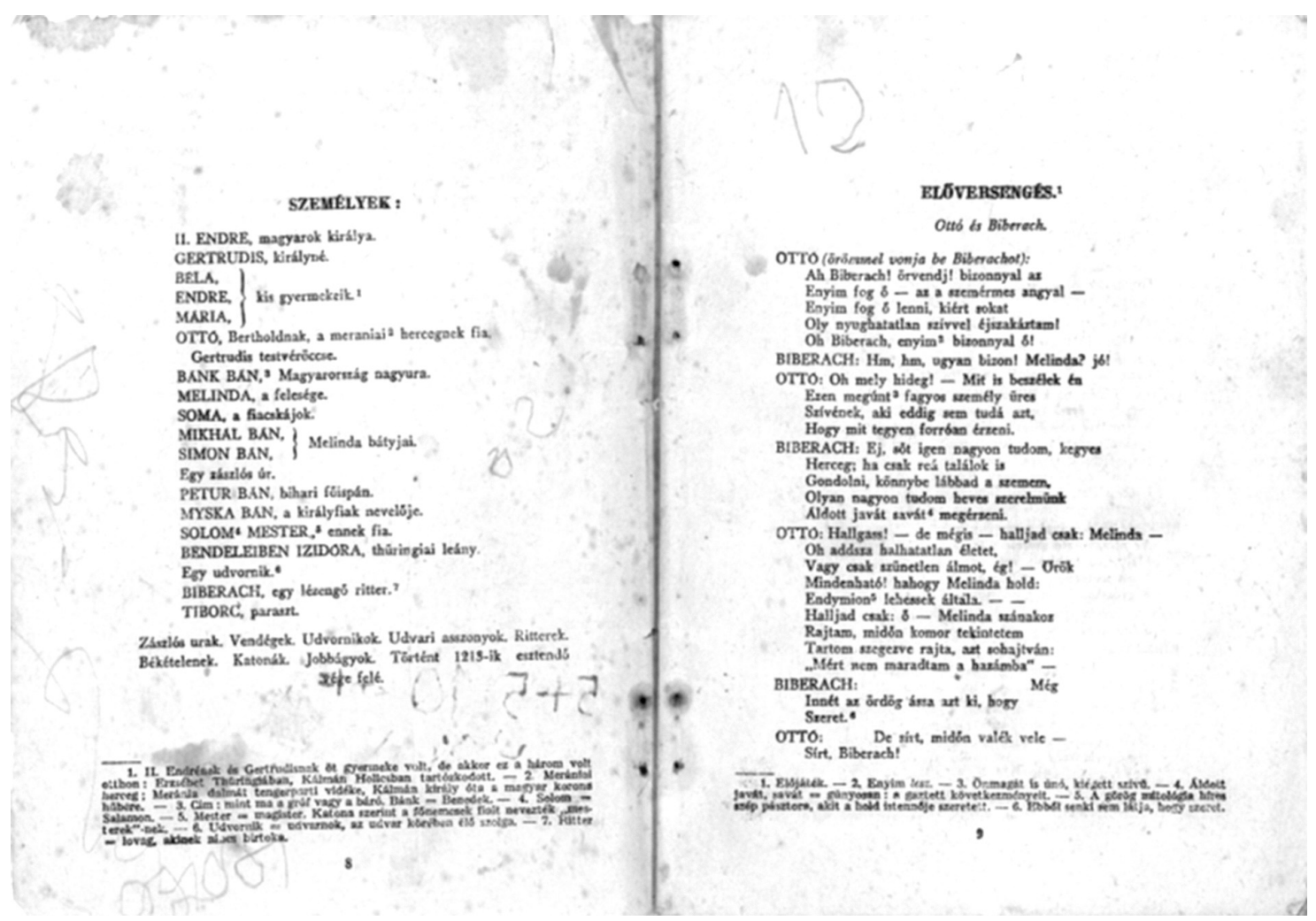

2. ábra. Katona József: Bánk Bán szövegkönyve (1933) 


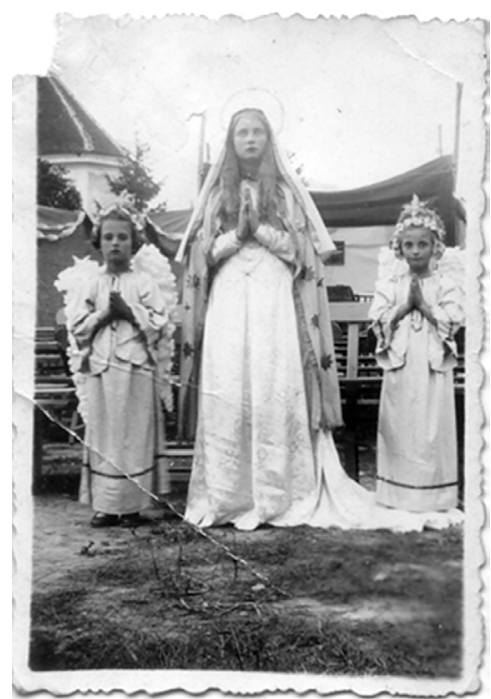

3. ábra. Szüz Mária Koronája címü színmü szereplői (1943)

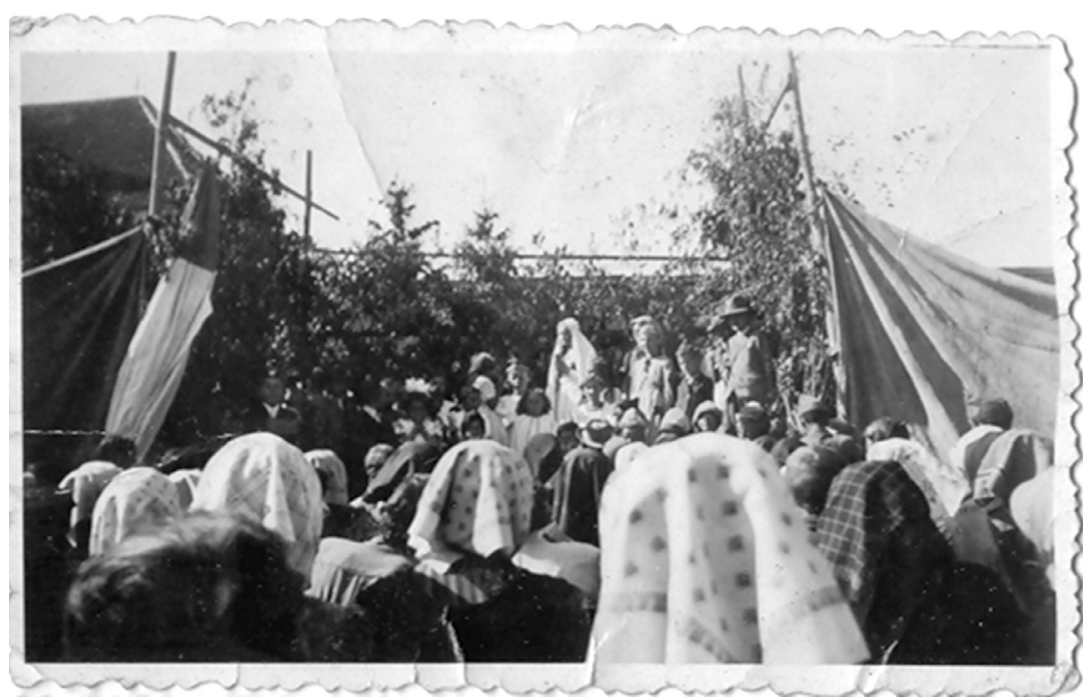

4. ábra. Szüz Mária Koronája címü színmü, föként asszonyokból álló nézőközönsége feladatokat is magában foglalta. „Kántor (lat. cantor, cantatrix): a liturgikus ének hivatalosan megbízott vezetője. - A kántor szó a lat. cantare, 'énekelni' igéből származik. Tágabb értelemben jelenti mindazokat, akik részt vesznek a liturgikus énekben (cantores), szoros értelemben énekvezető, előénekes. (...) A falusi kántorok 1948-ig kántortanítók voltak. Képzésük a tanítóképzőkben történt. Az iskolák államosításakor választaniuk kellett a tanítói és a kántorállás között." ${ }^{5}$ A népművelő: „A népművelést tervező, szervező, irányító, értékelő szakember főiskolai vagy egyetemi népművelői képzettségű. Szakfeladatai és elnevezése Magyarországon az 1950-es években alakultak ki, szakképzésük 1956-ban indult meg. Szaktudásuk lényeges elemei a müvelödés útjának, módszereinek az ismerete, a kulturális tervezés és a felnőtt nevelés módszertana. Munkájuk fontos iránya: a művelődési igények, a jelentkező szükségletek tanulmányozása, a müvelődés anyagi, szervezeti feltételeinek megteremtése, a művelődési programok vezetése, segítése, értékelése."6 Azonban a népmüvelői feladatkör a tanórákon kívül továbbra is a volt kántortanítókra, 1948 után a tanítókra várt többnyire. Ellenben nem csak a tanító rendezett színdarabokat, rátermett gazda vagy mesterember is vállalt rendezői megbízatást.

1943-ban A Szüz Mária Koronája címü színmüvet Fonóban vitték színre a háború alatt (3. ábra). Majd a szövegkönyv az 1950-es években átkerült Kisgyalánba Kalmár Sándor zsúpfedeles szülői házának a padlására, mivel vallásos témája miatt akkoriban nem volt célszerü Fonóban a tanító lakásban őrizni, mint mondták „a kommunizmus alatt, az orosz járás után."7A zsúpfedeles ház lebontásakor a szomszédban lakó Bóna Lászlóné (Széles Rózsa) nagynénémhez ke-

5 Kántortanító - Magyar Katolikus Lexikon lexikon.katolikus.hu

6 Read more: http://www.kislexikon.hu/nepmuvelo_a.html\#ixzz43pXP5UOt

7 Bóna Lászlóné Széles Rózsa (1930, Kisgyalán) szíves közlése. rült további megőrzésre. A mü Andocson íródott 1938ban, a Kaposvári Nyomda Rt.-nél került nyomtatásra. Megtudhatjuk belőle, hogy egy „minisztériumi rendelet e színmüvet felvette az engedélyezett színdarabok jegyzékébe." E szövegkönyv megvásárlásában bent van az előadási engedély is.

Andocs Fonó, Kisgyalán, Gölle, Büssü, búcsújáró kegyhelye ma is. A színmü cselekménye az andocsi Szüz Mária csodatételével válik teljessé. „Az ismert helyszín, a szereplők közelisége a helyi nézőt a lokálpatriotizmus büszkeségével ajándékozta meg." A színdarabot pedig Andocs közelsége miatt is sajátjuknak tekintették a fonóiak, bár a darab cselekményének színhelye egy nagyváros. A színmű nyelvezete világos, könnyen tanulható, ellentétben az 1934-ben Fonóban színre vitt Bánk Bán szövegével. Utóbbi szerepeinek tanulásakor nem lehetett könnyű dolguk a helyi fiatal embereknek. A Trianon utáni válság fokozta a hazafias érzületet, a hazaszeretet, a magyarságtudat erősítését célozta a Bánk Bán színrevitele is községünkben. Cséplő Rózsa visszaemlékezése szerin a próbák során a leggyakrabban elhangzott kételyek, és instrukciók ilyenek voltak: „Nem biztos, hogy el tudom játszani... Ezt bízzák rám! ... Odaerőtette a szípadra". A rendező bíztatta lelkesen amatőr színészeit, sőt kivitte a szereplöket a szabadba, ahol elég tér volt: „Ezt el kell játszani, értsék meg! ...Odaadással kell csinálni!”' Ezek akár a Bánk Bán kapcsán is elhangozhattak a szereplők és a rendező szájából. A Bánk Bán fennmaradt szerepkönyve (2. ábra) Fonóban Pál Elemér könyvespolcának egyik tagja, 1933 a kiadás éve, és már az azt követő évben színre is vitték a fonóiak. A szerepkönyv kiadása a kassai ősbemutató ${ }^{10} 100$. évfordulójára történt, és erre egy évre játszották a fonóiak.

8 Varga É. 1992: 241.

9 Cséplő Rózsa (1922-2015, Fonó) szíves közlése, Cséplő Lajos leánya, aki 90 évesen emlékezett vissza édesapja instrukcióira.

10 mnl.gov.hu/a_het_dokumentuma/a_cenzorok_es_a_bank_ban.html 
A későbbi darabokban szereplők az előbbiekről nem nyilatkoztak maguktól, mert ezekben még nem szerepeltek, hiszen még igen fiatalok voltak, vagy még meg se születtek.11 Azonban amikor a szövegkönyv kézbe kerülése kapcsán rákérdeztem a színre vitelét illetően, családi visszaemlékezések alapján válaszoltak: „Igen 1934-ben vitték színre. Édesapám Kovács Lőrinc szerepelt a Bánk Bánba, aki akkor 22 éves volt."12 Bármilyen téma kapcsán megfigyeltem, hogy a megörökíteni kívánt múltbéli eseményt, szokást, tárgyat az adatközlő annyira egyértelműnek tartja, hogy külön rá kérdezés nélkül nem tér ki rá, de az előkerült tárgyak, fotók, kéziratok, dokumentumok serkentik és pontosítják az emlékeiket, sőt idejét, helyszínét is. Kapos menti néprajzi gyűjtéseimben szerencsés helyzet állt elő. E vidék aránylag jómódú népessége körében korán elterjedt a fényképezés illetve fotóztatás a fontosabb eseményekről, talán jobban, mint a megye más tájegységeinek népénél, talán Csurgó környéke kivétel ez alól.

„Hogy e dramatikus jellegü szokásokat milyen sokféle szempontból vizsgálhatjuk, erre példaképpen idézem Ortutay Gyula kérdőívét betlehemes játékok gyűjtéséról. Szempontjait így csoportosíthatjuk:

- Szövegfilológiai és zenei szempont. (A szöveg és a dallam pontos, többszöri lejegyzése, rögzítése. Változatok.)

- Társadalmi vizsgálat. (A szereplő kora, társadalmi helyzete. A játszócsoport összetétele, etnikai és más szempontok szerint. A csoport tagjainak kiválogatása, a játszóközösség szabályai. A közönség és az előadás viszonya stb.)

- A népi közönségi színjátszás. (Próbák, betanulás, időpont, a közönség viselkedése, a játékhoz tartozó gesztusok rögzítése. Az előadás térrajza.)

- Művészi kivitelezés. (Maszkok, jelmezek, tárgyi eszközök stb.)

- A játékok célja. (Kultikus, pénzszerzés, szórakozás és szórakoztatás stb.)"13

„Külön hangsúlyt szeretnék fektetni a fényképekre, amelyek az 1920-es évektől készültek. Ezekből több példányt készítve főként csoportképeket osztottam szét - amikor még régi szokás szerint mindenki kint ült a kispadokon - azoknak, akiknél esetleg elkallódott az új ház építése során, vagy nem volt családtagjaiknak módjuk 80-50 éve hozzájutni. Örömmel tettem eleget a kéréseknek: „Te lány nekem is hozzá' belöle!”. Ezeken a képeken, egy-egy rögzített pillanat rámutat a falu összetartó erejére "14 - írtam már korábban. A csoportképek föként színdarabok, szüretibálok, iskolai csoportképek, gazdasági tanfolyamok, később a termelőszövetkezetben szervezett kirándulások alkalmából készültek.

Számunkra mára ezek a fényképek, szövegkönyvek maradtak kézzel foghatónak. A legtöbb előadás színhelye azonban a jelenkorban már nem létezik. Fonóban,

11 Valószínűleg, ez az oka, (mivel már nem játszottak benne) hogy az általam ismert falu monográfiák itt Somogy szerte sem tesznek említést arról, hogy a Bánk bánt színre került volna.

12 Kovács Gyula (1947, Fonó) szíves közlése.

13 Dömötör T. 1983: 7.

14 Lanszkiné Széles G. 2007: 9.-10.
Göllében, Nagyberkiben, egyaránt kiemelt színpad szolgálta a tartalmas szórakozás lehetőségét a helyi kocsmákban, amelyek azóta régen lebontásra kerültek. „Fonóban a kocsma felét elrekesztették fele színpad volt." „A Berki kocsmába be volt építve a színpad."15 A falusi kocsma még az 1990-es években is, az egyszerű ívó szerepén kívül több funkciót töltött be. Itt lehetett például vízdíjat befizetni, vagy a tejcsarnokból, vagy a mezőről hazafelé menet betérni, és a másnapi teendőket megbeszélni. Ez már a múlté ugyanúgy, mint a kocsmák színpadja, amiről a fiatal generáció már nem is hallott. A környező falvakban is hasonló volt a helyzet, amit a legtöbb község monográfiában megörökítettek a szerzők. Kadarkúton is a kocsma melletti kultúrteremben játszották színdarabokat az 1950-es évekig. Kaposfüreden szintén az 1940-es évekig a kocsma volt a színdarabok fő színtere, azt követően: „Egy Állomás utcai cselédházból a faluban élő iparosok készítették el a közösségi házat. 1945-ben hozzáfogtak új otthonok és egy közösségi ház kialakításához.”16 Somogyjádon „1956 után került napirendre a kultúrház megépítése, amit támogatott a járási és megyei hatóság. A lakosságnak is komoly anyagi áldozatot kellett vállalnia, ezért a tanács 15\%-os községfejlesztési pótadót vetett ki az építési költségek egy részének, valamint a járdaépítés fedezése céljából. ${ }^{17}$ Az 1950-es években a kocsmákból átkerült a színpad a volt intézőlakásokba, kastélyokba. Ezek híján, ha nem volt a községben nagyobb kisajátítható épület erre a célra, akkor minden esetben kultúrházak épültek, több esetben azonos tervrajz alapján (például Büssü, Taszár). Kisgyalánban kultúrháznak hívjuk a körülbelül 250 m²-es $^{2}$ épületegyüttest, amely a Festetics család tulajdonában funkcionált intézőlakásként 1949-ig. Ezt követően müködött benne könyvtár, posta, KISZ klub, attól függően, hogy mely egységét kívántuk igénybe venni, a szerint mondtuk: „Megyek a könyvtárba.” Azonban ha színdarab megtekintése, vagy éppen színdarabban való szereplés céljából kívántuk megközelíteni a kultúrházat, abban pillanatban már a „kultúrba” mentünk. Az öltöző minden esetben a könyvtárban volt és van. Kisgyalánban a színdarabokat 1950 előtt az iskolában játszották. „Hordtuk össze a hosszi deszkákat, lepedőket. Hosszi kocsi ${ }^{18} \mathrm{fe}-$ nékdeszkájából a pad tetejére 3-4 darabból lett a színpad, lepedőből pedig a függöny."19

Büssüben szintén az iskolában alakították ki a színpadot, az 1940-1950-es évek között. „A színpadot az iskolában, a tanteremben állítottuk ki. A padokat összetoltuk hátra, és a tíz méter hosszú, hat méter széles helyiségből leválasztottunk kétméternyit. Ide betettük a kocsmáros Krézinger Pali bácsi fabakjait emelvénynek, arra pedig a szomszédos parasztemberek kocsijainak deszkáit tettük.

15 Ennek a mondatnak a gondolat menetét tovább fűzve, romantikus képzeteket keltett, ahogy Farkas József (1929) visszaemlékezett, hogy egy-egy színdarab kedvéért, hogy nyargaltak el barátjával, édesapámmal Nagyberkibe, szörén ülve meg a lovat, megtekinteni a színdarabokat.

16 Puskás B. 2004: 174.

17 Kiss N. P. Polgár T. Szántó L. 2009: 182. - 183.

18 Hosszi kocsi: a lovasszekerek azon fajtája, amelyeket fa, széna, hordásának céljából meghosszabbítottak.

19 Farkas Józsefné (Bodó Rózsa 1936, Kisgyalán) szíves közlése. 


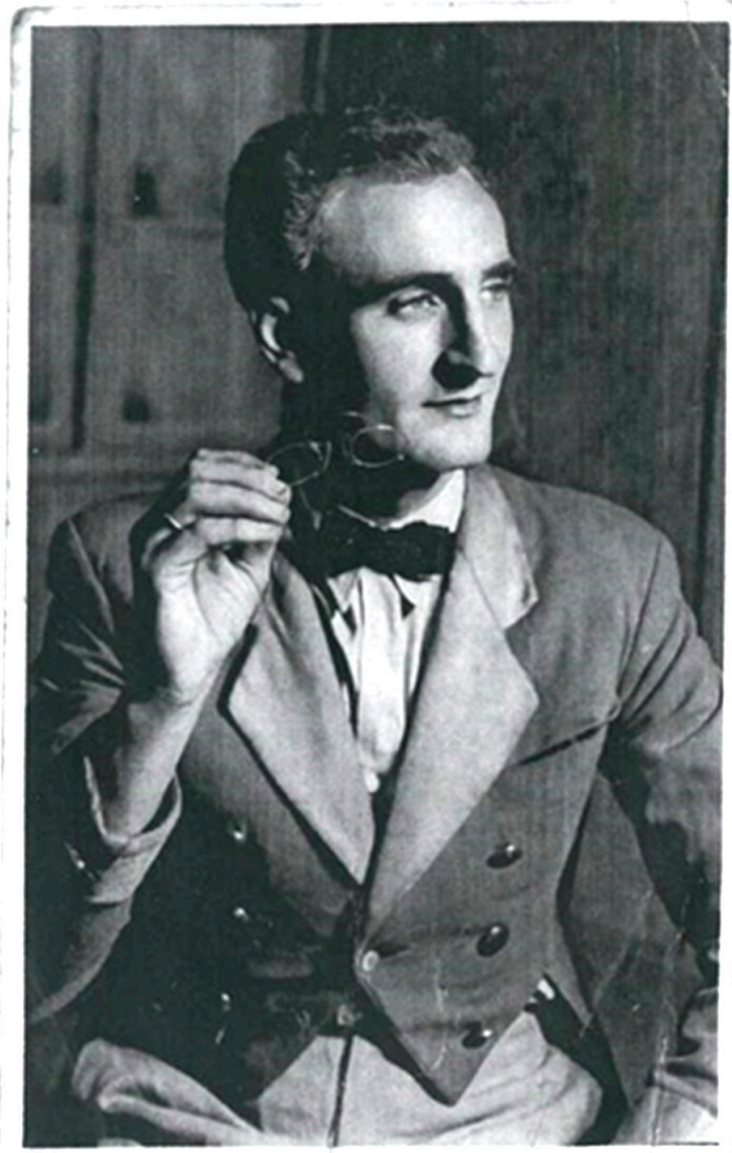

5. ábra. Szalai János a Göllében színre vitt Dankó Pista címü színdarabban

Ez volt a nagy mü. Járásokat nem tudtunk kialakítani az amúgy is kicsiny színpadon, úgyhogy nagyon kellett vigyázni, nehogy valaki eltévessze az irányt. A jelmezeket a környékbeli falvakból szedtük össze, így például Nagyberkiből, mert Büssüben nemigen lehetett megtalálni már a régi paraszti viseleteket, annál is inkább, mivel sváb község volt, már ami a katolikusokat illeti. A magyarok mind reformátusok voltak, ők viszont nem szerepelhettek, mert nagy volt az ellentét a két hitgyülekezet között. Szokatlannak tünt hát, de nagyon tetszett is a falubelieknek a sok bőgatya, a régi szoknya, buggyos ing." 20

Fonóban gyakorlati haszna is volt a színdaraboknak, amikor az újonnan elkészült pajtákban játszottak, a nézőközönség kellően ledöngölte az előadás végére a pajta földjét. Kellékeknek itt is kocsi deszkát, vászonlepedőket, csomagolópapírt kellett vinni a színpad megalkotásához. A színpad berendezése díszletek előteremtése is összefogással történt a 4. ábrát nézve: „Volt, hogy a régi iskola udvarán játszottuk. rudaló köteleket, ${ }^{21}$ nagy póznákat kellett kiteríteni, köré magaslat volt csinálva. Nagyaszszonykor lehetett, mert kint az udvaron játszottuk. Csak a lepedők, oszlopok látszottak, az asszonyok ültek, a férfiak csak á'tak hátul."22 A Szüz Mária Koronája 1943-es

20 Lévay Viktória 1998: 6.-7.

21 Rudaló kötél: széna-, szalmakazal leszorítására szolgál.

22 Szántó Imréné (Szabó Margit 1929, Fonó) szíves közlése.

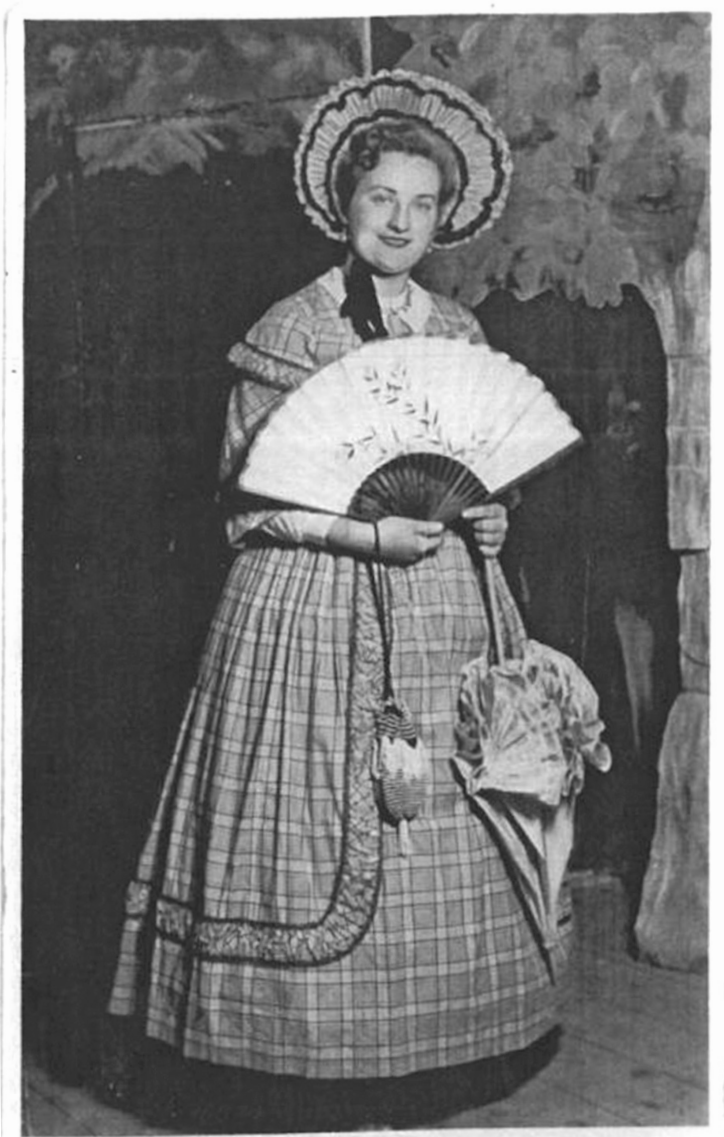

6. ábra. Szalai Jánosné (Sándor Etelka) a Göllében színre vitt Déryné címü színdarabban

háború alatti előadáson készült fénykép kapcsán hangzottak el ezek a szavak, a háborús előadás mivoltát a túlnyomórészt fejkendős asszony közönség bizonyítja. A fénykép jelenleg is fotóalbumban található, az emlékek megbecsülése jeleként. „A kultúrházban nem lehetett becsukni az ajtót, szorosan álltak a küszöbön is." Ezek a mondatok mindent elárulnak a teljes faluközösség érdeklődéséröl. „A színjátszás a falu életének fontos ünnepi alkalma, melynek hagyománya a messze múltba nyúlik vissza. A városnak sok szórakozási alkalma van: a városi ember válogathat a számára megfelelő szórakozási lehetőségek között. Falun azonban jobban, mint a városban a munka természete szabja meg a pihenés, a szórakozás idejét, s a tavasztól-őszig tartó szakadatlan szorgosság után a tél pihenőnapjait a jól megszervezett közösségi együttlét és kultúrmunka teheti élményszerūvé, széppé. Ez az asszonyokra még jobban vonatkozik, mint a férfiakra, hiszen a falusi illem az asszonyokat még mindig kizárja sok olyan szórakozási formából, mely a férfiak előtt nyitva áll. A kultúrházba menni viszont asszonyok, lányok számára szabad is, lehet is." ${ }^{23}$ Egy 1956-os újságcikk idézet is találóan fogalmazza meg, a falusi munka természetére tett utalást: „Az elöadás után Berényi János, a községi

23 Dömötör T. 1960: 22 


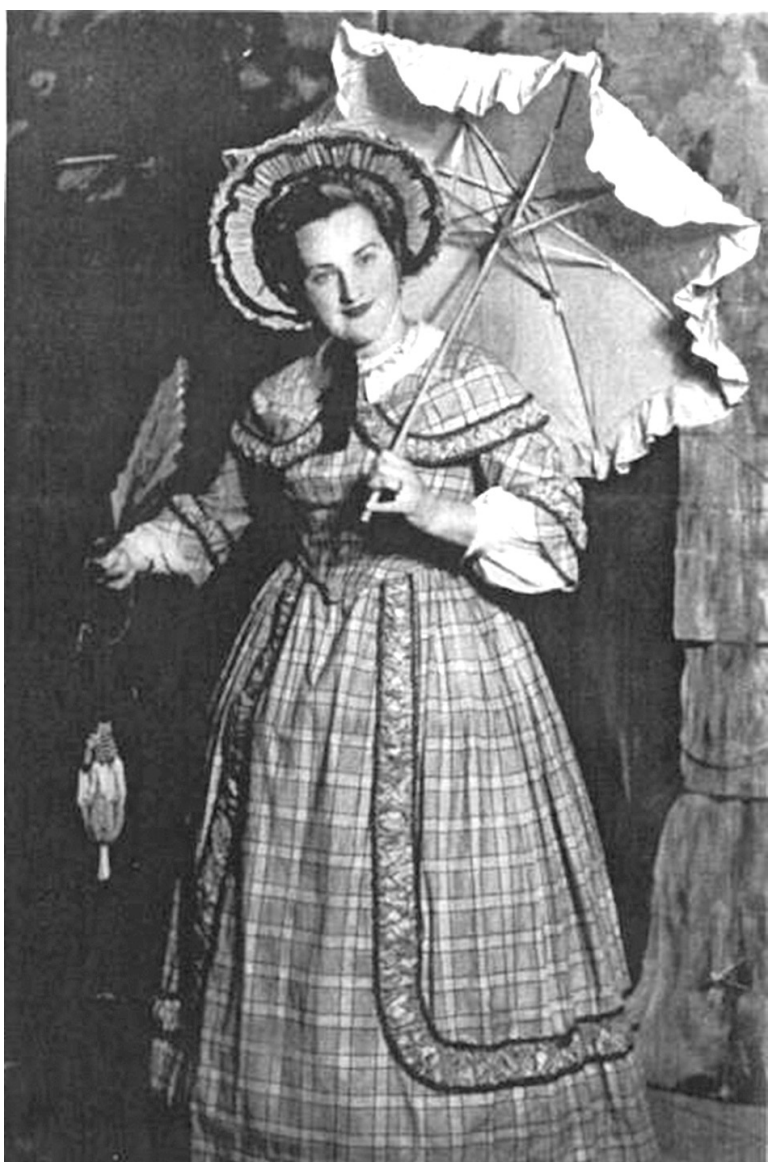

7. ábra. Szalai Jánosné

(1950-es évek második fele)

tanács vb- titkára elmondta, hogy Büssüben ezzel az előadással véget ért a „színiévad”. Most a nagy mezőgazdasági munkák ideje kezdődik, Mindnyájunkra - nehéz szerep: főszerep jut - kint a földeken." ${ }^{24}$

Az 1950-es évektől pedig, már egyre jobban tágult a világ. „Peströl kölcsönözték a ruhát, és küldték ide Fonóba." ${ }^{25}$ Göllében hasonlóképp hangzott el a mondat: „A ruhákat a kaposvári színházból szerezték be, volt mikor Budapestről hozták." ${ }^{26}$ (5-7. ábra). Természetesen nem minden esetben kölcsönzőből vagy a színház kelléktárából kerültek ki a jelmezek, hanem Cséplő Rózsa varrónő készítette Fonóban, aki fiatal korában, a színdarabokban is szerepelt (8. ábra). Vagy, ha a szükség megkívánta Gölléből hoztak át a szerep kedvéért pongyolát az 1950-es években, mert akkor még Kisgyalánban ilyen ruhadarab nem akadt. Az öltözék kiegészítéséhez szükségeltetett klipsz is: „A fülegombjához csíptették a klipszet.” A fülcimpáját nevezték így hangulatosabban, szemléletesebben, mint a köznyelvben.

„A Dodó (Cséplő Rózsa) a megfelelő ruhákat amire éppen szükségünk volt elkészítette, így segített. Fekete szoknya, fehér blúz a Tanítónőben, elegánsan voltunk

24 Szántó István: 1956. április 6. Somogyi Néplap

25 Kalmár Magdolna (1945, Zamárdi) szíves közlése.

26 Kutyik Gyuláné Szalai Ildikó (1955, Gölle) szíves közlése.

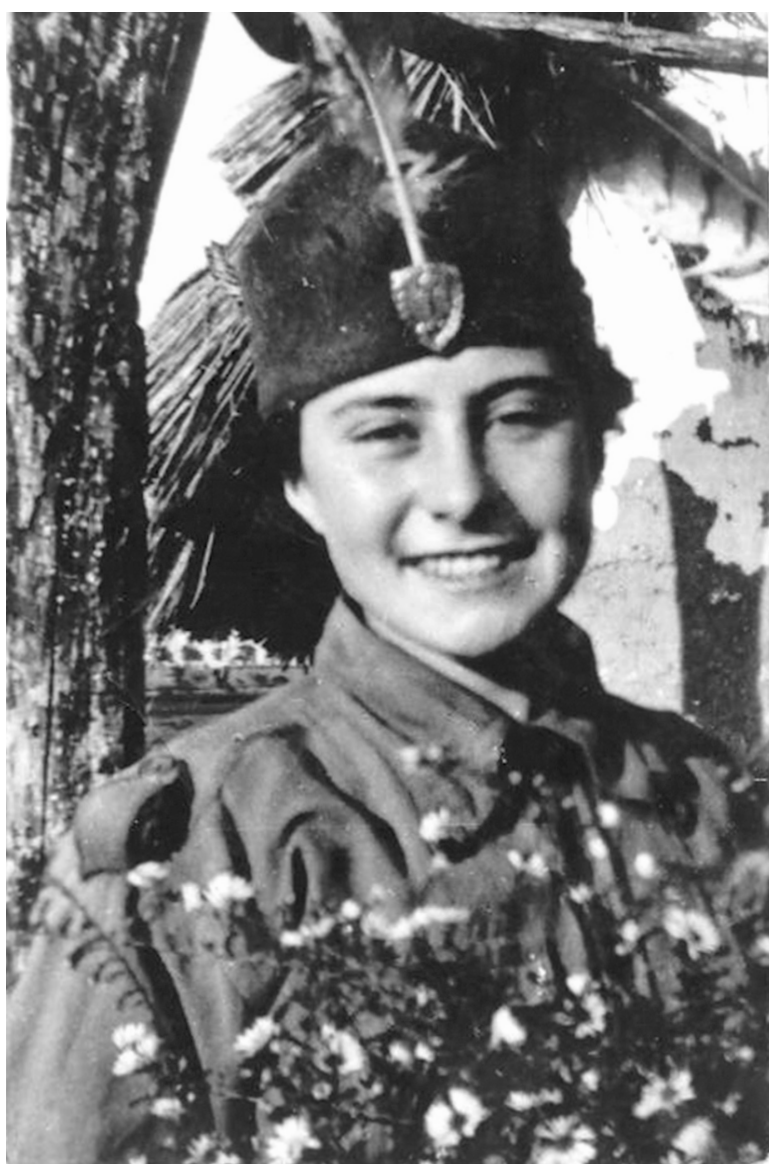

8. ábra. Cséplő Rózsa Fonóban a Szeget szeggel címü darabban (1930-as évek vége)

felöltözve.”27 (9. ábra). „Olyan a képen a Gyula bácsi, mintha valóban pap lenne (10. ábra), vidéki szereplés alkalmával külön ki is emelték a megjelenéséért, színészi teljesítményéért." ${ }^{8}$ Valóban, ezekről a képekről úgy tűnik mintha „igazi” színészek tekintenének le a képekröl. (11. ábra). Sokrétü, igen összetett feladat volt egy-egy színdarab megjelenítése. Kezdve a színpad összeállításán, a jelmezek előteremtésén át, a tanulás folyamatán túl az operettek zenei aláfestéséig.

„Fonóban, Bodó Pista, Kelemen Sándor voltak a zenészek, 2 darab hegedű is volt. Nagyobb faluban jobban akadtak ilyen zenészek." ${ }^{29}$ „Göllében Jakab Imre népi zenekara játszott, és énekelt. Tartalmas életet éltek." 30 Kisgyalánban kisebb falu lévén zenekar nem volt. „A Lukadér harmonikált.” 31 Büssüben: „volt egy nagyon jó furulyásunk, klarinétosunk (...) és egy hegedűsünk, Böröcz József, aki nagyszerüen tudott cimbalmozni is. Ök ketten a falu zenekarának tagjai voltak, de szívesen muzsikáltak nekünk is. A zenekar a színpad előtt kissé oldalt helyezkedett el, hogy ne zavarja a rálátást.” ${ }^{2}$ Mesztegnyő nagy községben, „az

27 Tót Fonai Györgyné Kálmán Magdolna (1936, Fonó) szives közlése

28 Szabó Gyuláné Gyurkó Piroska (1942, Fonó) szíves közlése.

29 Szántó Imréné szíves közlése.

30 Kutyik Gyuláné szíves közlése.

31 Farkas Józsefné szíves közlése.

32 Lévay V. 1998: 27. 


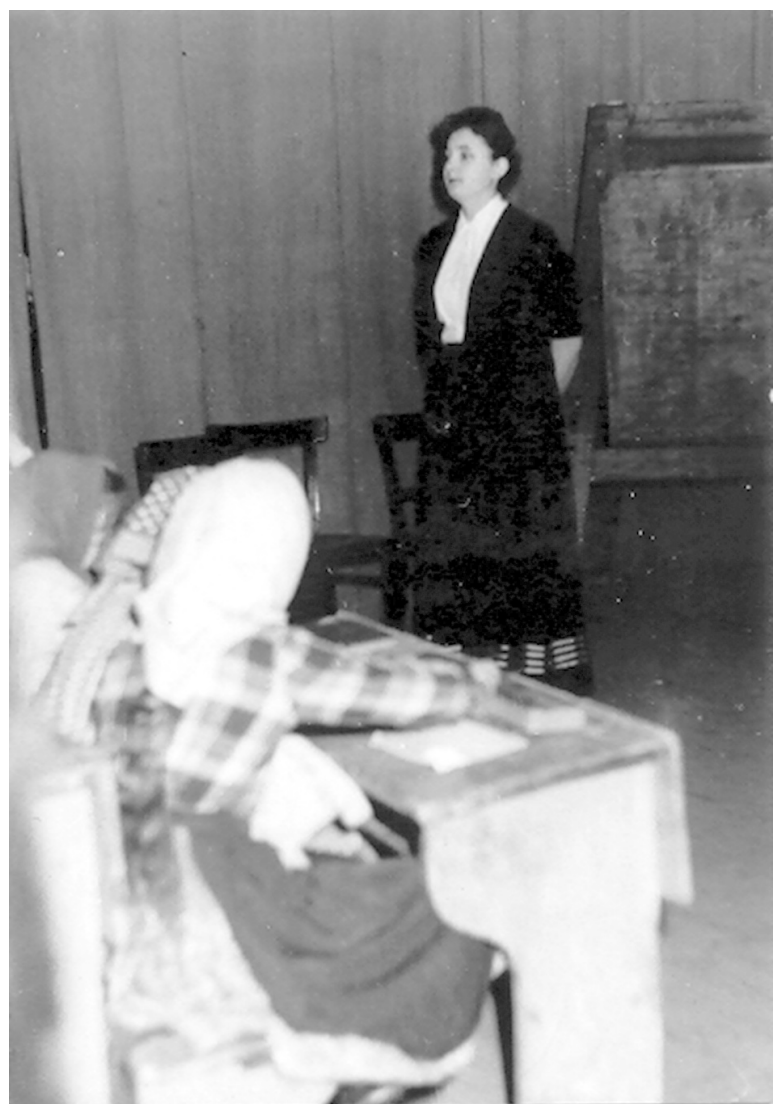

9. ábra. A tanítónő szerepében Kalmár Magdolna (Fonó)

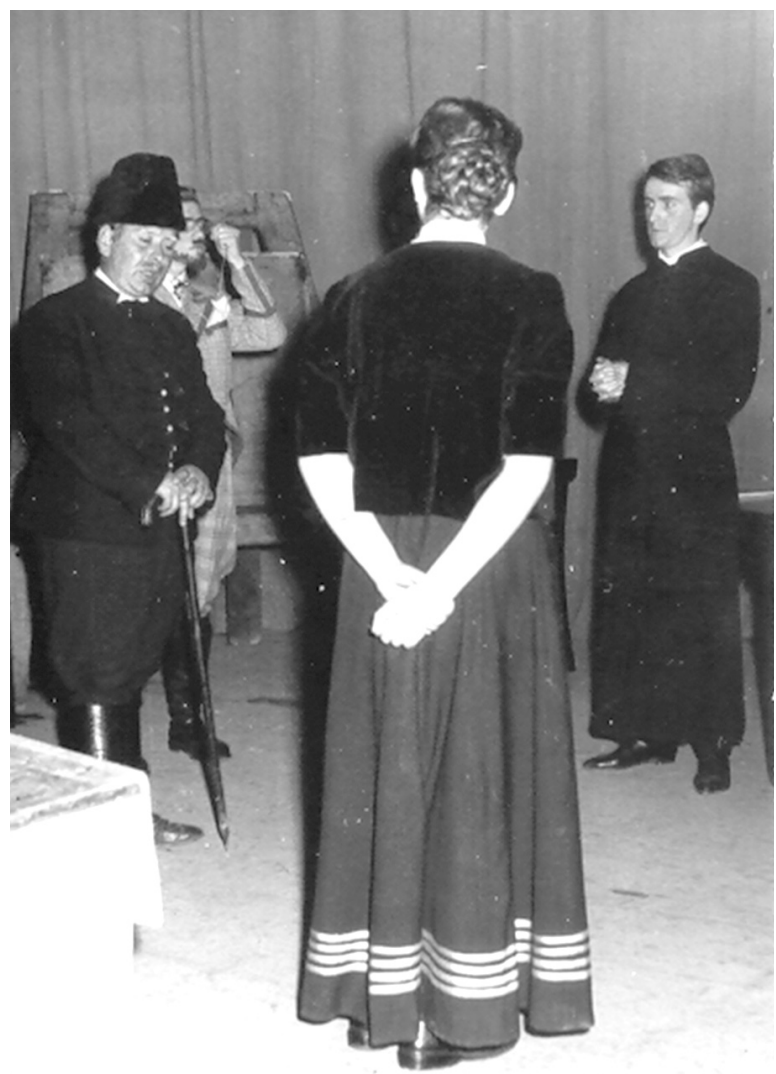

10. ábra. A plébános szerepében Szabó Gyula (Fonó)

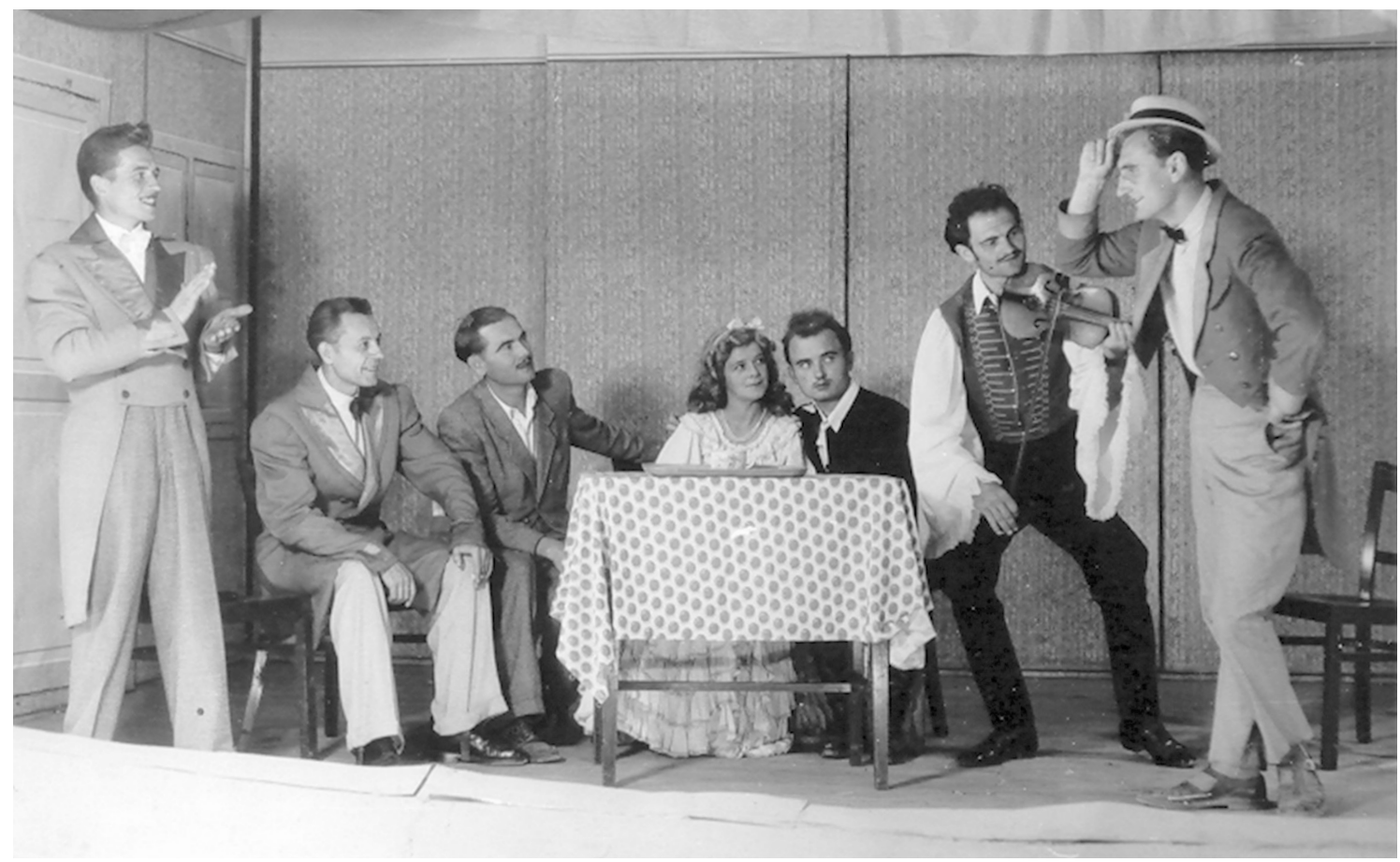

11. ábra. Gárdonyi József: Dankó Pista (Gölle) 
5 tagú Bors zenekar, 2 hegedűs, bőgős, cimbalmos szolgáltatta a zenét. Ezek a zenekarok általában az 1950-es évek elejéig nyújtottak szórakozást a falvaknak." 33 „A népszínműveknek is elmaradhatatlan dal-, zene- és táncbetétkellékei a cselekményben magában nem játszanak alapvető szerepet, a hangulati elemek fokozására szolgálnak, jelentőségük nem több mint szabadabb teret engedni az írónak, hogy a realitástól eltérhessen, s nótás - táncos, idilli jelenetekkel szórakoztassa a közönséget." ${ }^{4}$

A szereplők kiválogatása a darabot betanítónak volt a feladata, aki nem minden esetben a tanító, hanem valamelyik helyi gazda is lehetett Fonóban, Büssüben, Göllében egyaránt: „valamelyik középparaszt.”35 Kisgyalánban szinte minden esetben a tanító feladatkörébe tartozott, talán abból adódhatott így, hogy kisebb, kevésbé tehetős falu lévén a szerepkörök így inkább kötöttek maradtak. Tehát akként kapta valaki a szerepet, hogy:,Mennyi szereplő kellett hozzá, kinek milyen szerep való, a cselédek nem voltak ledegradálva." ${ }^{36}$ Ami itt nagyon fontos szempont, hogy az 1940-es évek közepéig a cselédsors megszűnéséig sem tettek különbséget egyik faluban sem cseléd, és parasztszármazású között, hanem a szerep elnyerésekor a rátermettség döntött. IIletve valószínűleg azonban ez sem ment egyik darabról a másikra, Büssüben sem: „A faluban persze híre ment, hogy cselédek is játszanak az előadáson, ráadásul nem is kis szerepeket. A gazdag parasztok egy része meg is jegyezte, hogy ők tartják el a tanítót, azaz engem, én pedig így viszonzom... Ezért a föpróbára alig jött el valaki. Viszont az előadás olyan nagy tetszést aratott, hogy a másnapi bemutatón kint a folyóson is álltak és onnan nézték. Egy idős bácsi meg is jegyezte: „Ez olyan volt, mint a Havas jegyző úr tíz évvel ezelőtti rendezése!" Ez bizony nagy dicséretnek számított." ${ }^{37}$

A szerep betanulásakor a szereplők egymás közötti és a rendezővel való viszonya érdekes lehetett, mert a tegezés magázás szabályai elég szigorúan voltak véve, főként az 1950-es évek előtt. „A színpadon a rendező letegezett. Itt alakult ki lépésenként minden." ${ }^{8}$ Varga Gyula az 1950-es évek második felében már ezt írja: „Közben a próbák alatt megkértek a gyerekek, hogy ne „magázgassam" őket, vegyem úgy, mintha a tanítványaim volnának, én pedig nekik „tanító úrból” Gyula bácsi lettem. Szép lassan megbarátkoztunk egymással, belemelegedtünk a játékba, kezdtük megismerni egymást és ígéretesen alakultak a próbák is." ${ }^{39}$ Egy-két helyi példa jól mutatja a tegezés-magázás viszonyát: „A kisgyaláni származású tanítót, Kalmár Sándort a vele egykorúak sem tegezték, miután a tanítóképzőt elvégezte, mivel tanult ember lett, „megmagázták”. Azonban ő természetesen kérte: „Úgy emlékszem tegeztél engem?” S így, a vele egyidősekkel továbbra is tegeződött. Érdekes példája a magázásnak az a történet, miszerint az akkori tanító úr az 1937-es há-

\footnotetext{
33 G. Jáger M. 2001: 150.

34 Varga É. 1992: 238

35 Puska Ferenc (1931, Gölle) szíves közlése.

36 Bóna Lászlóné szíves közlése.

37 Lévay V. 1998: 17.

38 Cséplő Rózsa szíves közlése.

39 Lévay V. 1998: 42.
}

zasságkötése után a sógorrá lett 8 éves intéző gyereket a többi korabéli gyerekkel magáztatni kívánta. A magázás nem tartott tovább 1 hétnél, mivel a kisfiú sírva kérte had tegezzék újra a többiek. Ennek oka, hogy szegénykét egy hétig verte a többi gyerek emiatt, intéző gyerek mivolta ellenére. A megkésett polgárosodás felé haladva, ezek a gyerekek már egy új generációt képviseltek, érezték mindkét részről, hogy ez a magázódás kicsit divatja múlt.

A néni, bácsi szólítás illette a megszólítottat, attól fogva mihelyt férjhez ment, vagy megnősült, annak ellenére, hogy alig volt korkülönbség, esetleg 5-6 év, vagy még annyi sem. Ettől kezdve természetesen nem is tegeződhettek. Jelenlegi 60-70 évesek körében gyakori még, ha már 10 év korkülönbség van, akkor az idősebb tegez, a fiatalabb magáz. Aki most 50 év körül jár, már a 20 év felettiekkel letegeződik. A II. világháború előtt a bátyám megszólítás is gyakori volt, nem rokonok esetében is. Ide kívánkoznak az ezzel a témával kapcsolatos történetek. Az 1930-as évek vége felé, mikor katonáskodás után hazakerült Széles (Tóka) József, minden lány bátyámozta (hiszen évek teltek el, míg nem találkoztak, és az idő is eltávolít egymástól). Erre fakadt ki: „Hogy vegyek el belőlük, ha mind bátyámnak szólít ?!” Így hát ő valóban más faluba ment feleségért, bár Mosdóson is „Dicsértessék a Jézus Krisztus!"-sal üdvözölte a leendő feleség is, ami tudvalevő, nem tegeződő ember köszöntése. Szabó Elek szintén így üdvözölte háztűznézőbe menetkor a lányos családot, mire a lány anyja így látta el jó tanáccsal a lányát: „Ehhez menjél férjhez lányom, mert ez szépen dicsért." A lány meg is fogadta."

Elképzelhető ennek ismeretében, hogy nem volt könnyü feladat a szerepbéli viszonyoknak is megfelelni, például kisasszony szerepben irodalmi nyelven megszólalni, vagy éppen szakácsnő szerepkörben a megszokott tájszólást alkalmazva: „Hát má' mé' lenne ez borzasztó." ${ }^{41}$ Cigány szerep is szinte minden darabban elő́rásszerüen előfordult, itt, ahogy a szerepekben le van írva, a zs betűk alkalmazása kötelező érvényű: „Já kérem! Ezseket el kell vinnem (...) Csókolom kezsiket, lábukat mindkettőjüknek. Adjon a Teremtő ezserennyit helyette." ${ }^{42}$ Ezenfelül figyelni kellett a szereplők egymás közti megszólítására is. Talán ezért volt általánosan elfogadott, hogy: „ha már menyecske lett, férjhez ment a lány, nem szerepelt színdarabokban." Későbbi évtizedekben már lazult ez a kitétel, már az 1950-es években is: „Nemcsak legényemberek szerepelhettek a darabokban, hanem nősek is."43 A színdarabok kapcsán az is szóba került, hogy még Szalai Jánosné is a Göllében színre vitt Déryné című színdarabban, a próbák közben haza-haza szaladt alvó csecsemőjét megnézni.

Az 1940-es években három faluval odébb lévő községből is elhívtak a fiúval rokonságban lévő asszonyt, hogy a feleségnek kiszemelt lányt nézze meg a színdarabban. Aminek eredményéről így szól az emléke-

\footnotetext{
40 Lanszkiné Széles G. 2007: 135

41 D. Kelemen A. 1938: 19.

42 D. Kelemen A. 1938: 40.

43 Bóna Lászlóné szíves közlése.
} 
zet: „A szerepben, piros bécsi bő szoknyám volt. Jöttünk haza a színdarabból, akkor mondta, hogy legyek a felesége." Az 1980-es évek elejére már teljesen más értékrend alakult ki. Azon túl, hogy egyre kevesebb darab került színre, a rendező tanár úrral szemben is egyre szemtelenebb lett az ifjúság, az egyre több iskolai elfoglaltság miatt. Alkudozásra is sor került, mondván akkor szánom rá magam a szerepre, ha a Tanár úr elkészíti az irodalom házi feladat verselemzésemet, amit Ö el is vállalt cél érdekében. Természetesen a korábban merev falusi ranglétra meglétének lazulása ellenére a tanító a falusi értelmiségi kör meghatározó tagja maradt továbbra is

Ekkor már az 1980-as években nem minden esetben szedtek belépődíjat, azt megelőzően jellemző volt határozott céllal, például Fonó, Kisgyalán Gölle esetében kirándulásokra gyűjteni a pénzt. Mosdóson „az iskola tetejére palát vettek” 44 a bevételböl. Büssüben: „a bevételből egyébként harmóniumot vettünk, illetve készíttettünk egy kaposvári mesternél, sosem felejtem el 180 forintért. Valahol még meg is van. Mikor Büssüben megszűnt az iskola, átvitték Göllébe. (...) Hogy minél többen beférjenek, kivittük az iskolapadokat az udvarra, mert ezek még azok a régi, hosszú egybeépített padok voltak, amiket én később modernizáltam, azaz elvágattam, végül, szintén színjátszós pénzből újakat vettünk." ${ }^{45}$ A csékúti színjátszók egyik bevételi bejegyzése: „Egy számomra érdekesnek tartott feljegyzés a pengő végnapjai körüli időkből, 1946. 04. 28-i előadás elszámolásából: „250 darab tojás s pár ezer mill. Pengő. 150 darab tojás a zenészeké a többi árán és a mill. Pengőkön egy tucat ceruzát, 100 darab tollat és 8 darab irkát vettünk, ekkor már a pénz óráról órára romlott." ${ }^{46}$ Kaposszerdahelyen 1935-ben a mükedvelő előadás bevételét a templomépítésre ajánlották fel a fiatal szereplők. „A falu rosszát március, május hónapokban a „Túl a Krivánont.” Sőt júniusban ugyanazt megismételték Kaposvárt, az Ipartestület nagytermében. A három előadásból a tanító 70 pengő tiszta jövedelmet szolgáltatott be. A sekrestye csengőjének beszerzésére szánom"47 Írta a következő évben 1936ban a kaposszerdahelyi plébános. Majd negyedszázad elteltével más irányelvek buzdították gyüjtésre a lelkes amatőr színészeket: „Példamutató kultúrmunka folyik például a karcagi Lenin termelőszövetkezetben. Seregélyes termelöszövetkezeti községben és még egy sor más helyen is. Hallottuk azt is, hogy egy ilyen csoport bevételéből traktort vásárolt.” "A bevétel növelése érdekében: Süteményt árultunk fiatalasszony lehettem. Belépti díj, volt jegyszedő az ajtóban, a tartalmas szórakozás lehetősége biztosítva volt."49

„Az előadást mindig irredenta dallal kellett kezdeni: „Kárpát földjén, Erdély bércén, Baranya felett, Zúgó szélben bús Rákóczi lelke kesereg. Horthy lovát kantá-

\footnotetext{
44 Frech J. 2013:73.

45 Lévay V. 1998: 7

46 Varga Gy. 2003: 90

47 Falutörténet I. - Kaposszerdahely www.kaposszerdahely.hu/mono/ 02_szerdahely.pdf 76.p.

48 Dömötör T. 1960: 26.

49 Szántó Imréné szíves közlése.
}

rozzák, rajta a nyereg, Szép országunk védelmére indul a sereg." Később, amikor már itt voltak az oroszok, az új rendszerben, nem lehetett ezt a nótát énekelni. Attól fogva kezdtük a Himnusszal az előadásokat."50 A szomszédos községekben is lejátszották a darabokat. „A nézőközönségben hátra kötött fejü asszonyok. Hat óra felé kezdődött téli időben az előadás, hosszú volt a téli este, de a jó nép nem szeretett barangolni késő este. Se tévé, se rádió, a tanító kötelessége az volt, hogy az ünnepekre készüljön el. A tanító osztotta el a szerepeket. Fonóba átmentem ingyen megnézni a színdarabot, mert öltöztettem a szereplőt." 51 Az 1980-as években, már nem mindenki tudott fökötőt kötni, ezért szükség volt idősebb tapasztaltabb asszony segítségére is, aki mint olvashatjuk mentesült a beléptidíj alól, mert így a stáb tagja volt. „A család ment a darabot megnézni, ha volt rokon szereplő, ha nem, lejátszottuk kétszer."

„Az öltözködéssel kapcsolatban fontos, hogy egyértelműen az a cél, hogy szüretibál esetén, semmiképpen ne a saját faluja viseletét öltse magára az adott falu népe, hanem más falvakét. A mi esetünkben, Kisgyalánban általános szokássá vált, az itt egykor paprikát áruló sióagárdi asszonyok viseletét felölteni. Pásztorjátékok esetén, szintén jelezni kell a játékosságot. Ez úgy nyilvánul meg az öltözékben, hogy a bekecset, kucsmát ki kell fordítani, úgy kell felvenni! Ezt minden falusi szülő tudja. Mikor néptáncos gyerekeinket Kaposváron öltöztettük a pásztorjátékokra, a göllei anyukák gondolkodás nélkül ösztönösen, épp úgy kifordították a kucsmát, mintahogyan én is, így nyomtuk a fiúk fejére. Visszafordítatták velünk a kucsmát. Mi értetlenül néztünk egymásra: „ezt nem úgy kell!” Mi még így tanultuk gyerekkorunkban, de a városban már ez a szál elszakadt." ${ }^{2}$ Pásztorjátékoknál még az 1980-as években is láncos botot csörgöttek rászögelték a láncot és lekoppantották falvainkban.

„Gyalánból Zimányba mentek, Gölléből Gyalánba. Hívogatva egymást, Fonóba, Büssübe. Heténybe 3 kocsival, mentek a Héjjass tanítóval. Mentünk magunk is a színházba. Bóna László Heténybe vitte a szereplőket, lovaskocsival Gyalánból.” „Ezért Bodó Jenő a tartozás fejében Harkányba hívta vissza fürödni, visszaszógáta.” „Mezőcsokonyára a fiatal embereket is elvitték, nemcsak a nőtleneket"53 Ezek már az 1950-es évek történései közé tartoznak. Az egymásközti értékrendre is figyelmesek lehetünk, „visszaszógáták”, az egymásnak tett szívességek nem maradtak viszonzatlanul. A kisbíró feladatai közé tartozott az 1970-es évek közepéig, hogy kidobolja hol, és mikor veszi kezdetét a színdarab. Fonóban gyerekként Szántó Kálmán rajzolta a plakátokat, aki iparművész lett. Kisgyalánban nem volt jellemző a kiplakátozás.

„Karácsonyi időszak után farsang, álarcosbál, az után színdarabok jó szerivel azután, madarak fák napja." A visszaemlékezések során a madarak fák napja is több alkalommal említésre került, a színdarabokkal kapcso-

\footnotetext{
50 Lévay V. 1998: 7.

51 Bóna Lászlóné szíves közlése.

52 Lanszkiné Széles G. 2011: 196

53 Bóna Lászlóné szíves közlése.
} 

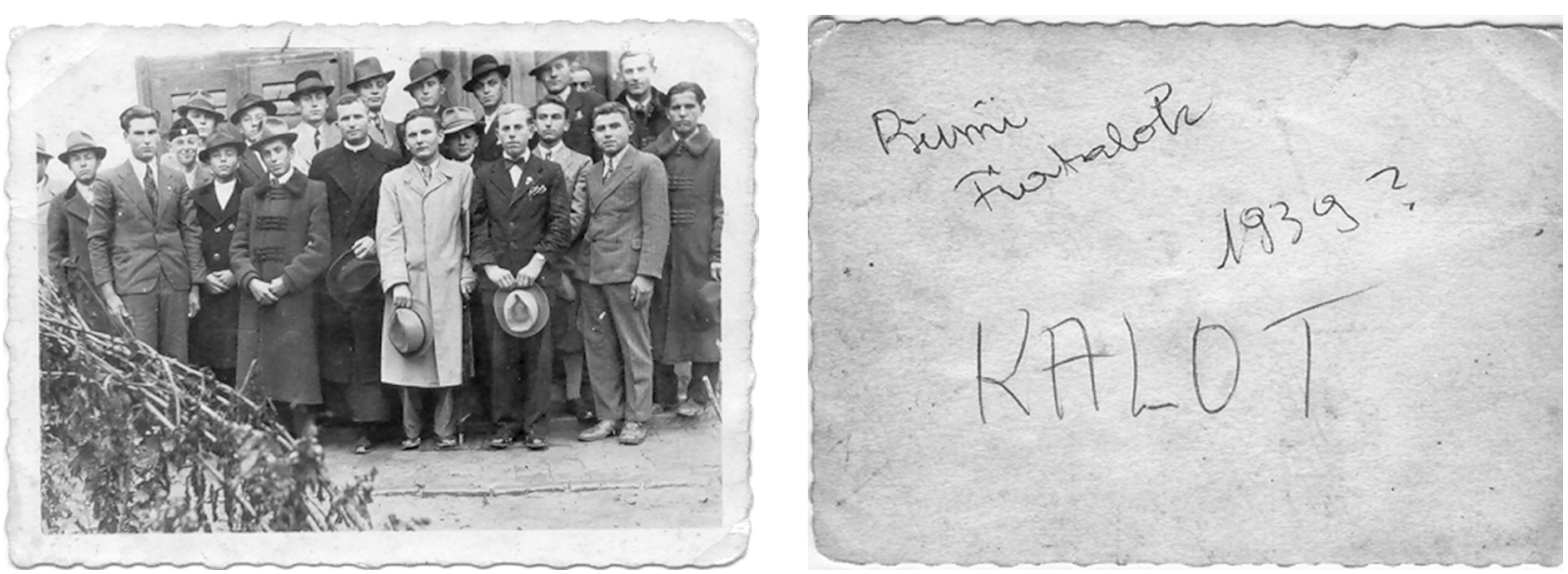

12-13. ábra: Büssüi fiatalok a KALOT-ban (1939)

latos gyűjtéskor. Ami szintén az összetartozást erősítő tevékenységek közé tartozott községeinkben, ugyanúgy törvénycikk szabályozta 1906-ban. A műkedvelő színjátszást gróf Klebelsberg Kúnó, kultuszminiszter határozottan szorgalmazta a nemzetnevelés programjának keretében. „1924-ben a Vallás- és Közoktatásügyi Minisztérium rendelete alapján határozták meg a legfontosabb feladatokat: analfabéták oktatása, népművelési előadások tartása, népművelési tanfolyamok szervezése, népfőiskolák, szabadegyetemek működtetése, ifjúsági és népkönyvtárak szervezése, ismeretterjesztő irodalom terjesztése, műkedvelő előadások, tanfolyamok támogatása." ${ }_{4}$ „Az 1920-as évek elején a fokozatos konszolidációt nagymértékben elősegítette, hogy a hazai kultúrpolitika és a közoktatásügy irányítása gróf Klebelsberg Kunó kezébe került, aki a kultúrát tartotta a fejlődés elsődleges mozgatórugójának. Kultúrpolitikájában nagy súlyt kaptak a nép művelődését szolgáló és a közoktatást fejlesztő intézkedések. Klebelsberg szerint a vesztes világháború, a forradalmak, a trianoni békediktátum mind hozzájárultak ahhoz, hogy hazánk politikai tekintélye $\{\mathrm{V}-461$. csökkent, gazdasága tönkrement, jövője bizonytalanná vált, a lakosság hite, önbizalma szertefoszlott. Ebben a helyzetben a felemelkedés felé egyetlen út vezet: egy újszerü nemzeti érzés kibontakoztatása az emberekben, melynek alapja az a felismerés, hogy a magyarság nem rendelkezik számottevő nyersanyagkészlettel, gazdasági erőforrásokkal, de hatalmas kulturális értékek birtokában van. Időtálló értékű kultúránk egy magas szintű, korszerű oktatási és művelődési intézményrendszer keretei között jelentős további értékeket hozhat létre. Az ország felemelkedésének fontos tényezője tehát a kultúra minél szélesebb rétegekre való kiterjesztése. Ebből a sajátos „nemzetnevelési” programból következett, hogy a magyar művelődés egész intézményrendszerét modernizálni, fejleszteni szükséges." 55

„1922-ben, a 123500/1922. számú VKM rendelettel felállították az Iskolán kívüli Népművelés Országos Bizottságát, amelynek véleményező és tanácsadó sze-

54 Egyletek,olvasókörök,mükedvelöcsoportokSulinet www.sulinet.hu/oroksegtar/data/.../017_egyletek_olvasokorok.htm

55 Magyarország a XX. században / Kultúrpolitika és ... - MEK www.mek.oszk.hu/02100/02185/html/1362.html repet biztosítottak. Klebelsberg nagy volumenű terveit csak az 1925. november 25-i nemzetgyülésen terjesztette elö. Kiemelte, hogy a várossal szemben a falusi népet kell felkarolni, a népművelésnek elsősorban a paraszti kultúra megbecsültségére, elismertetésére kell törekedni, majd a középosztálynak, az értelmiségnek a művelődési igényeit kell megszervezni és kielégíteni." 56 „Az emberi természet kettőssége, testi és szellemi törekvéseinek párhuzamossága arra kényszerít bennünket, hogy mindkét dolgot egyidejüleg műveljük: a magyar földet is, a magyar lelkeket is." $1929^{57}$

Szervezetten színdarabok a KALOT-on keresztül is jutottak a falvakba az 1930-as évek végétöl, tovább pezsdítve a már addig is élénk kulturális életet. Fonóban, Göllében, Büssüben (12-13. ábra) is szerveződött KALOT, amire mind a négy községben felhívták a figyelmet. Értékrendjéről tanúskodnak a KALOT által kitüzött célok: Krisztusibb embert! Magyarabb magyart! Életerős népet! Műveltebb falut! Kerkai Jenő hozta létre a KALOTot, aki jól ismerte a falvak életét. „A Központ segített az Egyletnek, hogy igényüknek, müveltségüknek megfelelő irodalmi anyagot, verseket, színdarabokat kapjanak, melyet az egyleti összejövetelek tanulmányi részében megtanultak, megismertek. Az egyszerü falusi legényeknek meg kellett tanulniuk a hallgatóság előtti fellépést, valamilyen téma közös megvitatását, verseket, népdalokat kellett megtanulniuk és elöadniuk, színdarabokat betanulni, magukat szakmai vonalon képezni. Szerves része volt a KALOT egyleti önképzésének a társadalmi illemszabályokba való bevezetés is." ${ }^{8}$ „A KALOT, Katolikus Agrárifjúsági Legényegyesületek Országos Testülete, 1938. okt.1946. júl. 4.; 1988. nov. 24.-: a földmüvesek és földmunkások legényegyleteit vagyoni helyzetre és vallásfelekezetre való tekintet nélkül összefogó országos szervezet. - Célja a krisztusibb ember, a müveltebb falu, az életerős nép és önérzetes magyarérdekében az agrárifjúság szellemi, anyagi támogatása, összefogása és érdekvédelme. A KALOT a szociális enciklikák szellemében, polgári

56 Ahazaifelnőttképzéskialakulásánakfejlődéseésfőbb..www. kulturasz.hu/letoltes/A hazai felnottkepzes tortenete.pd

57 GRÓFKLEBELSBERḠKUNO POLITIKAI HITVALLÁSA - MEKmek. oszk.hu/09700/09782/09782.htm

58 https://hu.wikipedia.org/wiki/Kerkai_Jenô 
pártoktól függetlenül fogta össze és egységesítette az agrárembereket, a törpe- és kisbirtokosokat. Meghatározó szerepe volt nemcsak a falu népe lelki és kulturális életének fölemelésében, hanem a nincstelen parasztság embertelen szociális helyzetének megváltoztatásában is.”59 Göllei visszaemlékezés a KALOT-ról: „KALOT az ifjúságot foglalkoztatja, összefogja 1946-ig célja volt a Katolikus Egyház Eszménye. A pap vezette, tanító is beleszólt adott esetben." ${ }^{0}$

A KALOT megszüntetése után már haladt a maga útján a színjátszás, nem volt megtorpanás. Ezt követően az új politikai hatalom is fontosnak tekintette a színdarabok tovább élését, sőt ettől kezdve a községek különböző seregszemléken erejüket is összemérhették, színpadra termetségüket illetően. Bár az 1940- es évek második felétől a világnézet változott, a vallásos darabokat és a népszínműveket más müfajok váltották fel. Kisgyalánban még ma is (2016) szállóigeként él az alábbi mondat: „Lenin a Renben ${ }^{61}$ élt!” Ami az 1950-es évek vége felé hangzott el az akkor tizenéves gyerek szájából egy színielőadás keretében, aki akkor még nem volt tisztában a Kreml történelmi épületegyüttesének fontosságával. Amivel derültséget keltett, a történelem viharai következtében egyre szélesebb látókörűvé vált a nézőközönség. A KISZ Magyar Kommunista Ifjúsági Szövetség 1957-1989. feladatkörébe tartozott a színdarabok seregszemlére vitele is.

Fonóban az emlékezetben élő színdarabok a következőekben kerülnek felsorolásra. A legrégebben játszott darabok esetében, a szerzők nevét nem őrizte meg az emlékezet. Ezzel ellentétes példa, saját visszaemlékezésem szerint az 1980-as évekből a szerző neve - Federico Garcia Lorca - maradt meg az emlékezetemben a többi szereplőnek úgyszintén, a mű címe nem, pedig még seregszemlén is szerepeltünk vele. Valószínűleg sajnos sok értékes lejegyzésre méltó történet kirostálódott az emlékekből, több színmüvel kapcsolatban is.

\section{A Fonóban bemutatásra került színművek, amiket megőrzött az emlékezet:}

A legkorábbi színdarabról készült csoportkép 1915-ből származik (14. ábra). A hátoldalán olvasható: „Ezen fénykép készült 1915-ben. Jelen vannak a színdarab előadók" (15. ábra).

Két világháború közötti népszínművek:

Katona József: Bánk bán, Shakespeare: Szeget szeggel (8. ábra), Csepreghy Ferenc: Piros bugyelláris, Tóth Ede: A falu rossza.

Három kislány ül a padon: Csak nők játszották. Lányok fiúnak felöltözve, Göllében is elöadtak olyan darabot ahol, csak nők szerepeltek az előadásban.

Iskolás darabok az 1930-as években: Pepi néni a darab címe. „Pepi egy tehén volt”, Kanadai ötös ikrek: „csak a fejünk volt kint, azon volt a fejkötő, cumiztunk.” Röpke kis emlékképek maradtak meg ezekről a darabokról.

59 KALOT - Magyar Katolikus Lexikon lexikon.katolikus.hu > K

60 Puska Ferenc szíves közlése.

61 Ren: gáztűzhely, sparhet, sütő része.
Juhászlegény, Légy jó mindhalálig, Hófehérke, Égig érő fa, ezeket már nem pontosan beazonosítható talán az 1940-50-es években vitték színre.

Piros bugyelláris, A falu rossza, leggyakrabban ezekröl a népszínművekröl emlékeznek meg a község monográfiák is, kedvelt darabjai voltak falvainknak. Könnyed, szórakoztató népszínművek. „A népszínmű olyan drámai műfaj, mely témáját a nép életéből meríti, szereplői az 1870-es, 80-as évekre csaknem kizárólag népi alakok. A cselekmény mozgatórugója többnyire a szerelem, a darabok befejezése általában megnyugtató." 62 „A közönség szórakozni akar, nevetni, ámuldozni, nem gondolni a hazai problémákra. Az egykor társadalmi mondanivalókkal induló népszínmű falusi tárgyú operetté sekélyesedett, álparasztokkal és álnépdalokkal. Népszerü a kalandos „látványosság”. Mindehhez felettébb alkalmas szerző Csepreghy, aki mesterien megtanul fegyelmezett szerkezetü, fordulatos és boldogan végződőszínjátékokat írni, hol szellemesen pergő, hol feszült hangulatú dialógusokban. Ekkor fordul a legnépszerübb s immár leghígabb színpadi játékhoz, a népszínmühöz. Igen jó ötlete támad: a nem kevésbé divatos detektívregények témavilágát átülteti a magyar falusi, illetve álfalusi környezetbe. „A sárga csikó” és „A piros bugyelláris” szerelmi bonyodalmakkal teljes, énekes-táncos, megnyugtatóan „happy end”-es bűnügyi dráma. A darabok népszerüségét mi sem bizonyítja jobban, mint hogy 1879-ben a császári pár ezüstlakodalmi bécsi koncertjén „A piros bugyelláris” képviseli dalaival és a Török bíróné menyecskejelmezébe öltözött Blahánéval Magyarországot. A fiatalon meghalt Tóth Ede igen jól megírt falusi játéka, „A falu rossza” mellett ez a két Csepreghydarab évtizedekig a legtöbbet játszott népszínmű." ${ }^{3} \mathrm{~A}$ falu rosszát 1916-ban, A piros bugyellárist 1917-ben már meg filmesítették. A piros bugyellárist 2016-ban a televízió újra vetítette, erre felhívták a figyelmemet, ezzel további emlékek kerültek elö, a mü dalai eléneklésre kerültek.

A II. világháború alatt színre vitt vallásos színdarabok:

Szűz Mária koronája (3-4. ábra) 1943. 06. 09. szövegkönyvét, és fényképeit egyaránt megőrizte az utókor, a visszaemlékezés pedig így szól: „Mária voltam, angyalok a Rózsika, és a Bori voltak. Taszáron is voltunk vele. Cséplő Lajos irányította a színpad építését. Édesanyám varrta a ruhát. Cséplő Jenő tanította be a darabot. (Nagy Imre mellé került.) Pásztorjátékot is szoktunk tanulni, ezek a templomban voltak lejátszva." 64

A mi falunk: „Darab a háború alatt, szentképet helyeztünk a színpadra, letérdeltünk a Szüzanya képe elé. (Bátyám akkor volt katona.)" Mondat foszlányok maradtak meg az emlékek közt, több mint 90 évesen: „Szent Szűz adj erőt nekik, hogy fussanak.” Az Intéző Spórer ${ }^{65}$ azt mondta: „Dodókám tudod, hogy megríkattál!”,Ó Szent Szűz Rejtsétek el őket Ti Angyalok, Ti Szent tiszta Angyalok Vigyázzatok rájuk, Nagyon rájuk, Az lenne a legjobb."66

62 Varga É. 1992: 237

63 www.szineszkonyvtar.hu - 2007. Csepreghy Ferenc Életrajz www.szineszkonyvtar.hu/contents/a-e/csepreghyfelet.htm

64 Szántó Imréné szíves közlése.

65 Spórer Intéző Urat pedig biztosan nem könnyű volt megríkatni, mert inkább keménykezűnek volt mondható, mint érzékenynek.

66 Cséplő Rózsa szíves közlése 


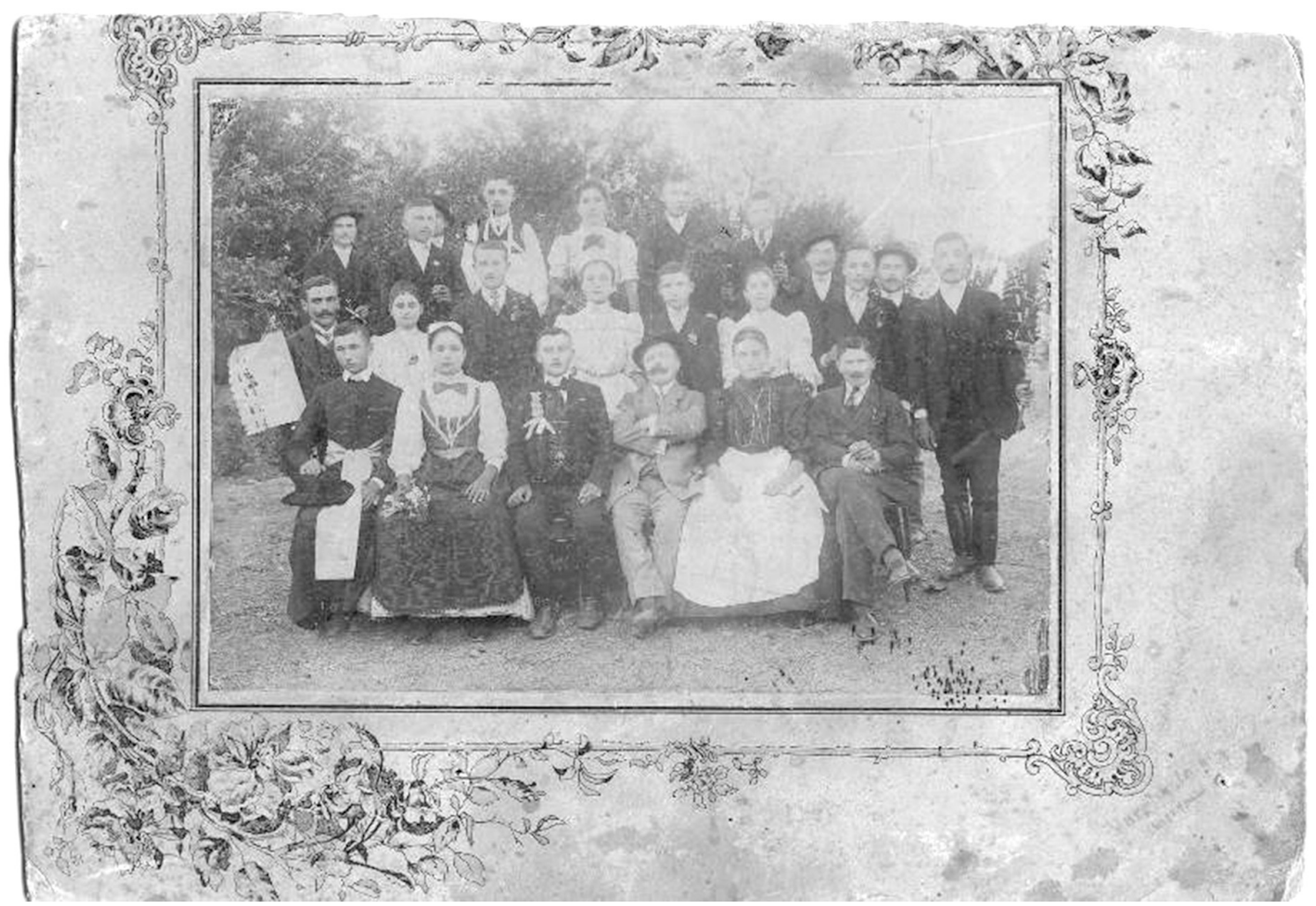

14. ábra. A legkorábbi fonói színdarabról készült csoportkép (1915)

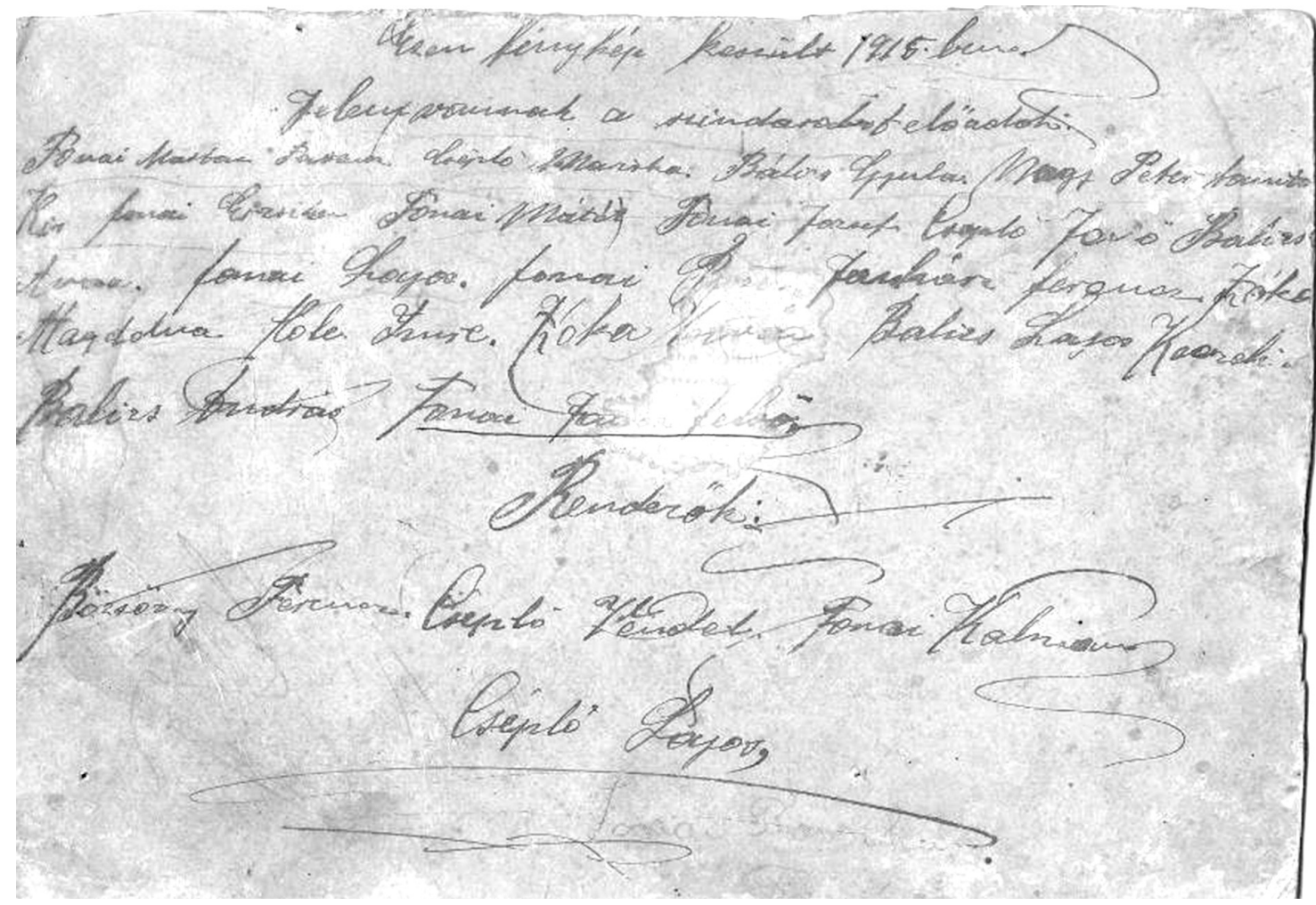

15. ábra. Az 1915-ben készült fénykép hátoldala 
A II. világháborút követő darabok: a címek sokat sejtető, egyszavas, beszédes címek. Földindulás. Szakadék, Virradat. A három cím azt sugallja mintha összetartoznának. Kodolányi János: Földindulás, ezt Fonóban 1945-ben adták elő. A két világháború között játszódik a gazdasági válság közepette, az akkortájt falvainkban „dívó egykézés” adja a mü alapgondolatát, ezáltal aktualitást nyerve. 1939-ben magyar játékfilm is készült a müből. Szabó Pál: Szakadék 1955-ban vitték színre Fonóban. „Egy feltörekvő paraszt a hőse: ahogyan az a gyermekkor, a háború, majd a forradalom viszontagságain átvergődve felnő s nagy próbák és küzdelmek árán eljut önmagáig. Itt ér véget a regény, ahol a megtalált élet kezdődik. A tárgy maga régi és irodalmilag sem éppen érintetlen: a szakadék, előre sejthetöleg, a falu népe és a falu intelligenciája között fog fölmeredni; igen, a háború és a forradalom után - a regény legvégén - tátong föl hirtelen egész váratlanul, mint ahogyan a szakadékok hasadni szoktak." 67 Virradat címmel igen sok mü látott napvilágot, igen sok szerzőt megihletett ez a pozitívumot sejtető cím.

„Az Erdei kápolna csodáját Taszárra mentünk át megnézni, akkor határoztuk el, hogy ezt "magunk is megcsináljuk." ${ }^{\mathrm{A}} \mathrm{A}$ fiatalság „helyből való kimozdulása," a mások kultúrmunkájának megismerése formálta-bővítette az ifjúság világról alkotott képét, esetenként növelte önbizalmukat. A színdarabok célt adtak a hosszú téli esték hasznos eltöltésére. Együtt tanulták be a közösség számára pihenésre, szórakozásra lehetőséget adó színdarabokat. „Angyal tanító néni rendezett, sok színdarabot játszatott. Sok ének volt a darabokban, sokat énekeltünk. Minden télen összegyültünk, 1015-ször próbáltunk el egy darabot." Ezek a darabok sokszor párhuzamosan futottak az egymás szomszédságában lévő községekben. Arra is volt példa, hogy a kaposvári Csiky Gergely Színházban is müsorra tűzték az egyidejüleg Fonóban játszott darabot. El is mentek a fiatalok Bródy Sándor A tanítónő című színmüvét megtekinteni a színházba. Azt a következtetést vonták le, hogy ők sokkal lelkesebben játsszák a darabot, nem olyan unottan, mint a színészek. A hivatásukat gyakorlók mentségére szóljon, hogy sokadszorra előadva már csökken a lelkesedés." ${ }^{69}$ A legnagyobb visszhangot ez a darab keltette. Fonóban szinte mindenki megemlékezett róla, díjat is kapott elismerésül. „A Kalmár család nagyon sokat áldozott a faluért. Mindent elkövettek, hogy Fonó kibontakozzon, Fonót felemelni volt a cél. Gyalánban is lejátszottuk a Tanítónőt."70 A tanítónőt a Kalmár házaspár tanította be. Tanítónő a két egymást követő szereposztásban Tót Fonai Györgyné (Kálmán Magdolna), majd Kalmár Magdolna volt. „Összetartó volt a Fonai falu, Búcsú után, egész tavaszig szinte minden hónapban játszottunk színművet. Szeretettel köszöntjük a mi ünnepünk vendégeit a Kultúrban, hangzott el műsorkezdéskor. Elegánsnak kellett lenni.

67 Szakadék - Kultúra - 1939. július - Huszadik Század www.huszadikszazad.hu/kultura/szakadek

68 Pintér Gyuláné Zóka Mária (1925-2010, Fonó) szíves közlése.

69 Lanszkiné Széles G. 2013: 170.

70 Bráz Andrásné Bertalan Eszter (1935, Kaposvár) szíves közlése. 1954-ben Böhönyében játszottuk. Jól összeválogatott csapat volt. Seregszemlére jártunk, 2 hét alatt meg kellett tanulni a darabot. Nagyon nagy sikerünk volt nyáron, kirándultunk a bevételből. Mindenki szinte az egész falu részt vett az előadásokon, sok virágcsokrot is kaptunk. A Kalmár házaspár a színdarabokon kívül is foglalkozott mindenkivel, törödtek velünk, azt is megkérdezték, nap mint nap: Magdi milyen napja volt ma? Összehangolták, kire milyen szerep illik."71

Operett, zenés mesejáték: 1950-60-as évek darabja. Szirmai-Emőd: Mézeskalács. Ezt a színdarabot is a Kalmár házaspár tanította be, lányuk Kalmár Magdolna így emlékezett vissza: „Versengés volt a két település között, egy évben játszottuk a Mézeskalácsot Büssüvel, Ök is eljöttek ide. Télen a szüleim 1-2 napra felmentek Budapestre színházba. Bánki Zsuzsa játszotta a Tanítónőt. Nagy hatással volt Édesanyámra, sírás nélkül nem állta meg az előadást. Ekkor elhatározták, hogy ők is megrendezik ezt a darabot. Amikor nem kellett Pestre menni a ruhákért, Dodó varrta a ruhákat. Az 1960-as években, jól szervezett színi adottságok, egész estét betöltő programok voltak Fonóban. A vásári élmény közvetlen volt a Mézeskalácshoz, kalapos mester volt Nagyapám, így a példákat az életből merítették. Elvitték többször is a darabokat más községekbe. Édesapám Gyalánba ment legszívesebben.” „Nagyobb helyre tudnánk menni, de kedvesebbre nem." - mondta szülőfalujáról Kalmár Sándor. „Hónapok mentek rá a próbákra, ez volt a szórakozásunk. Kézbe tartották a gyerekeket, a próba héttől-tízig tartott. Zenei betétek megtanulása sem volt könnyű. Édesapám a dalokat tanította. A Mézeskalácsban a főbb szerepek: Fonai Erzsébet: királynő, Örzse: Cséplő Márta, csizmadia: Juhász János. „Munkamegosztás” volt. Sokat adtak arra, hogyha nem beszélnek akkor is játszanak, arcjátékot. A szövegkönyvek ronggyá lettek szakítva mire betanulták." 72

Móricz Zsigmond: Sári bíró 1952 vígjáték, amelyből 1943-ban készült film. Mint a cím sejteti ez a színmü is egy faluközösségben játszódik, és egy faluközösségnek történik az eljátszása. Azonban ez már nem csupán egy kedélyes népszínmü, amiket az 1920-30 közötti években adtak elő. Itt már a könnyedségen túl társadalombírálattal is találkozunk, a valóság egyre jobban szerepet kap a múvekben. A cselekmény a bíró választás körül bonyolódik.

Gárdonyi Géza: A bor címü darabja 1954-ben került színre Fonóban, ${ }^{73}$ Kisgyalánban pedig az 1980-as években.

\section{Politikai, aktuális, sorskérdésekkel foglalkozó da-} rabok:

Az életmódváltás problémájával foglalkozik Galgóczi Erzsébet: Aknamező (16. ábra) című műve. A darab akkor került bemutatásra Fonóban mikor már lecsitultak a kedélyek a téeszesítésekkel kapcsolatban.

71 Tót Fonai Györgyné Kálmán Magdolna szíves közlése.

72 Kalmár Magdolna szíves közlése.

73 Bráz Andrásné szíves közlése. 


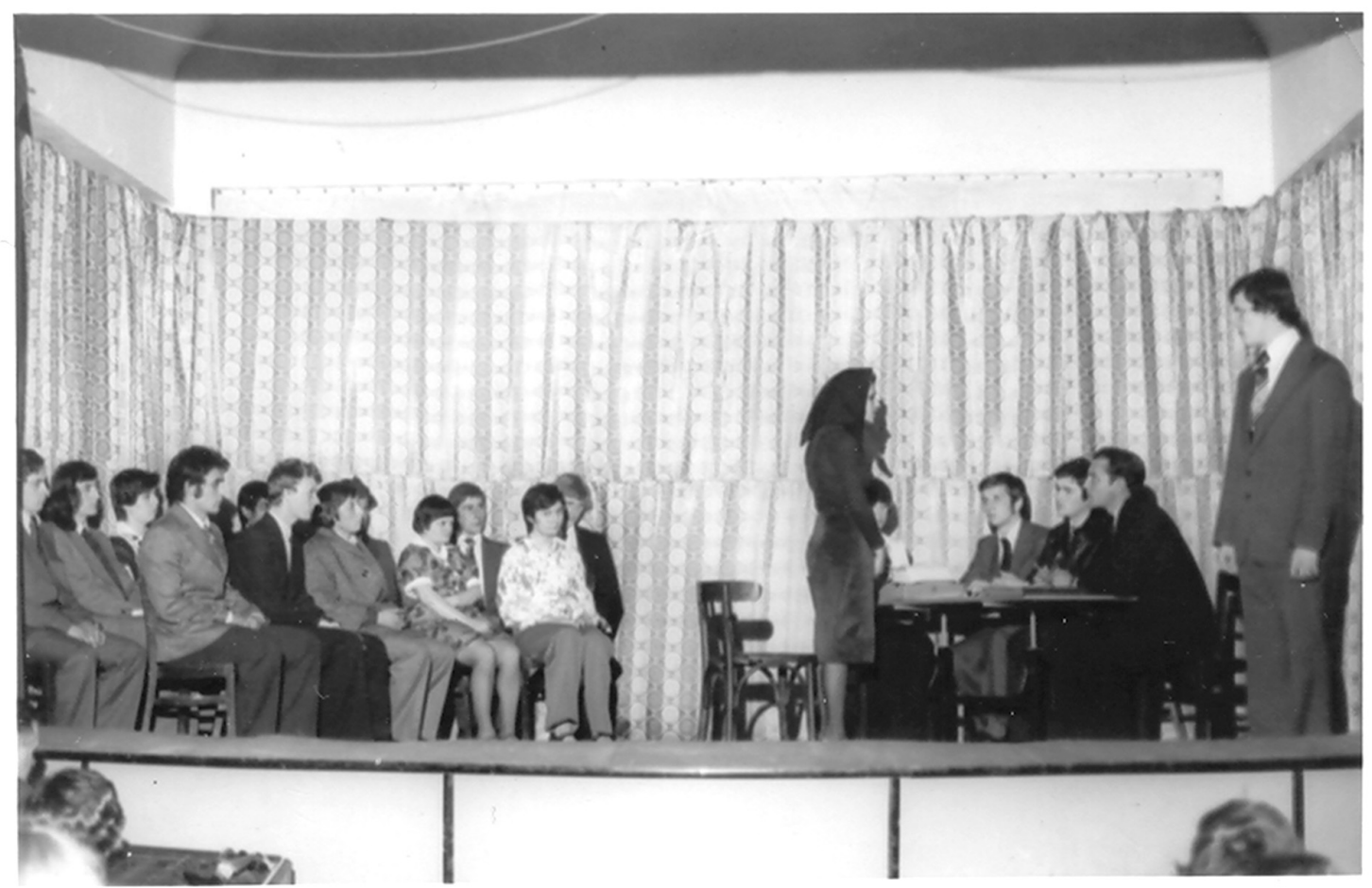

16. ábra. Galgóczi Erzsébet: Aknamező című színdarabjának jelenete (rendező: Kalmár Sándor, 1977)

„A szerző bemutatja a paraszti világot, a parasztság problémáit, lelki vívódásait, konfliktusait családon belül és a környezettel. Árnyalt ábrázolás, finom lélekrajz jellemzi, az eseményeket alakító paraszti érzés- és gondolatvilágnak, életmódnak a feltárása. (...) Tanúi lehetünk, hogyan ragaszkodik a parasztság a maga földtulajdonához a kollektivizálással szemben. Különösen az idősebb generáció nem tud változtatni attitüdjén, de a fiatalok is csak nehezen. Az Aknamezőben özvegy Török Jánosné gyilkosságot kísérel meg fián, mert az belépett a téeszbe."74

A termelőszövetkezetek fennállása alatt, a tagokat rendszeresen színházbérlettel látta el a termelőszövetkezet, természetesen oda-vissza utazást biztosítva tagjainak. Az előadások után kritikát ${ }^{75}$ is gyakoroltak az épp aktuálisan megtekintett darabról a tejcsarnokba menet, vagy épp mezei munka közben, egymást is megbírálták például ha elaludt valaki a nehéz napi fizikai munka után a színházban. Azonban mindig várta a tagság ezeket az alkalmakat, kellemes kikapcsolódást nyújtott, valamint csinosan fel lehetett öltözni az elöadás tiszteletére, most is megemlékeztek róla, hogy ki milyen ruhát viselt egy-egy előadás alkalmával.

Egy szintén szállóigeként megmaradt történet, egy baranya megyei faluból Pécsre történő színház látogatását örökíti meg. A Bánk Bánt játszották, azonban a tsz tagok nem érkeztek meg az előadás kezdetére, és amikor odaértek Bánk bán épp azt a kérdést tette fel a színen: Honnan jöttök parasztok? Mire a válasz: „Somberekből csak lerobbant a buszunk!"

74 Mogyorósi László tanulmánya - BárkaOnline

www.barkaonline.hu/tarca/2159-mogyorosi-laszlo-tanulmanya

75 Kritika alkalmával a pozitívumokon kívül, elhangzott a ripacs szó is.
Az 1980-as évek után már egyre ritkábban kerültek színpadra darabok. Az általános iskolát befejezők ekkor még inkább tovább tanultak, vagy már az utazással járó kötött munkaidő is kevésbé tette lehetővé a próbákat, a televízió térhódítása is rossz irányba vitte el a színvonalas időtöltés lehetőségét.

\section{Kórustörténet}

Ezek a szomszédos községek Kisgyalán, Fonó, Büssü férfikórust is alapítottak. Büssü volt az alapító, a kórus nevét Kisgyalán adta és persze tagokat is, a legtöbb kórus tagot majd a kórusvezetőt is pedig Fonó adta. Így együtt: „A színdarabokban is érvényre juthattak a szép hangú szereplők, akik kórust alapítva Országos Hírnévre is szert tettek. „A kisgyaláni »Petőfi« Mg. Termelőszövetkezet férfikórusa (17. ábra) 1968-ban alakult. Tagjai többsége a termelőszövetkezet fizikai dolgozója, köztük traktoros, állatgondozó, szerelő, gépkocsivezető stb. és vezetésben dolgozó egyaránt megtalálható. Akiket nem fáraszt a heti két próba, lelkesít a dal szeretete, a kultúra terjesztése. Müsoraikban népdalok, Kodály-, Mozart-, Bárdos-művek szerepelnek."76

A 9. országos minősítő hangverseny 1984. május 5-i eredményének méltatása így hangzik: „Az időbeli sorrend helyett hadd kezdjük az ismertetést a »meglepetéscsapattal«, a Nagy Endre által nagy tudatossággal irányított kisgyaláni férfikarral, mely - figyelem! - a legmagasabb minősítést, a fesztiválfokozatot szerezte

76 Az énekkarra vonatkozó dokumentumokat Papp Ferenc volt kórustag (1947, Fonó) bocsájtotta rendelkezésre, ezekböl következnek a továbbiakban idézetek. 


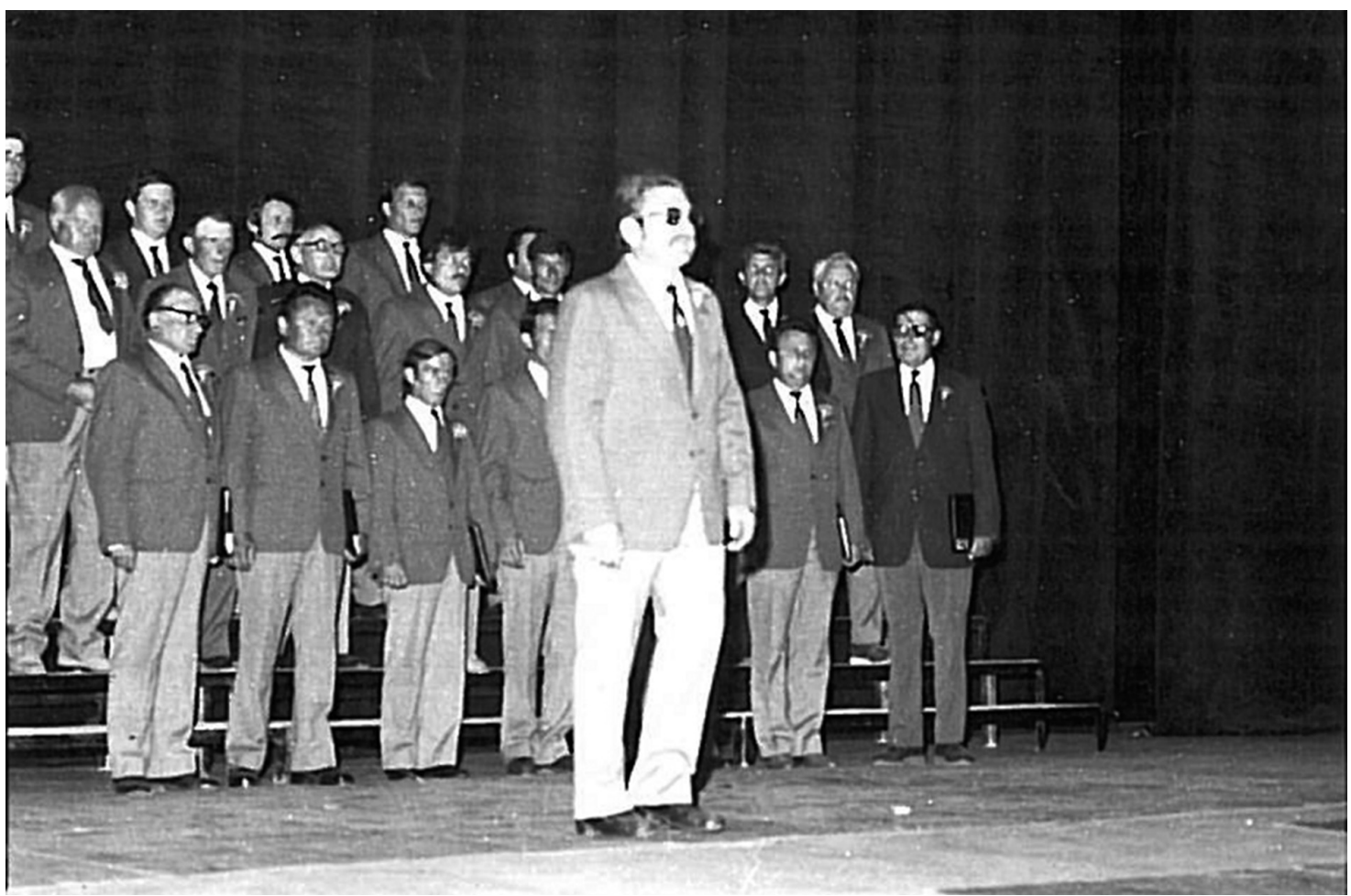

17. ábra. A Kisgyaláni Férfikar

meg. Vecchi, Mozart, Jeep kompozícióinak előadásával nagyszerü stíluskészségről tett tanúbizonyságot ez a mindössze huszonnégy tagból álló, de hangerejével is a népes dalárda hatását kelteni képes együttes. Karai József mủvének, a Kecskeméti toborzónak interpretálását pedig valóságos szuperlatívuszokkal méltatták az ítészek sodró lendületéért, tisztaságáért, stiláris biztonságáért. Egy mindössze ezernyolcszáz lelkes »háttérrel« ilyen kórust kialakítani bizony nem mindennapi teljesítmény!" Ez a lelkes háttér, és maguk a kórus tagok is Fonó, Kisgyalán, Büssü lakosságából került ki. „Ugyanebben az évben a megyeszékhelyen szervezett Felszabadulási Kórusversenyen az országos hírü »Vikár Béla« kórussal megosztott első helyezést kaptak. 1985-ben folytatódott a sikeres szereplés. A szövetkezeti kórusok számára hirdetett országos versenyen - 84 kórus közül - bekerültek a legjobb húsz közé, s ezzel jogot kaptak a Szolnoki X. Országos Kórusversenyen való részvételre. Ez az év hozta a külföldi rednitzhembachi férfikartól meghívást kaptak a Német Szövetségi Köztársaságba 1986 májusára (18. ábra)." A Magyar Rádió Zenei Főosztálya rádiós felvételt készített 1991-ben a kórussal. Az Éneklő Magyarország Kórustalálkozó minősítő hangversenyén 1994ben arany minősítést kapott a Kisgyaláni Férfikar."

\section{Göllében előadott színdarabok}

Göllében is az előadásokról készült igényes fotók magukért beszélnek. Azonban ha a Gölle szót meghallja valaki, az első gondolata gondolkodás nélkül Fekete István. Fekete István is játszott Göllében, angyal szerepben az 1907 körüli időkben, vélhetöleg Gölléből a legkorábbi hiteles, derüs és egyben az eredményt illetően Fekete Istvánt, mint gyereket elszomorító leírás. Itt megtudhattuk, hogy a taps Göllében a 20. század előn még nem volt szokás, ${ }^{77}$ mint tetszésnyilvánítást alkalmazni, a befolyt jövedelmet pedig kiosztotta a Tanító Úr a szereplök között.

„Én is hétéves lehettem akkor. Tél volt, havas arcú, békés tüzű karácsonyváró tél, és mi pásztorjátékra készültünk a göllei iskolába. Én voltam az egyik angyal. Ma sem tudom, hogy gondoltak rám ennél a megtisztelő szerepnél, mert az ördögök is tanulhattak volna tölem egyet, s mást, de angyal lettem a világ színe előtt, s ehhez mért komolysággal tanultam szerepemet. Közben - mint angyal - behógolyóztam Puskáék ablakát, és beszakadtam a malomgát vizébe, ahol aztán majdnem angyal lettem a szó legszorosabb értelmében. (...).

Ezen előzmények után elérkezett a várva várt nap. Szárnyakat kötöttem, fehér ingbe bújtam, és hatalmas izgalommal vártam a jelenésem.

A színház - azaz iskola - zsúfolásig tele. A nagy gőzben a lámpa nagyon gyengén mérte a fényt, de a görögtüz segített a dolgon, és a közönség áhítatos csendben leste a fejleményeket.

77 Az 1970-es években már annál inkább tapsoltak. Ennek a történetnek a felidézésekor, hangzott el az alábbi szintén Göllében lejátszódott esemény. A Kaposvári Csiki Gergely színház vendégszerepelt Göllében. A Kisgyaláni Petőfi, és a Göllei Béke Termelöszövetkezet tagjai vettek részt az elöadáson, göllei, kisgyaláni, büssüi, és fonói, emberek. Az előadás csak nem akart elkezdődni, ezért a nézőközönség megelölegezett tapssal invitálta színpadra a színészeket. 


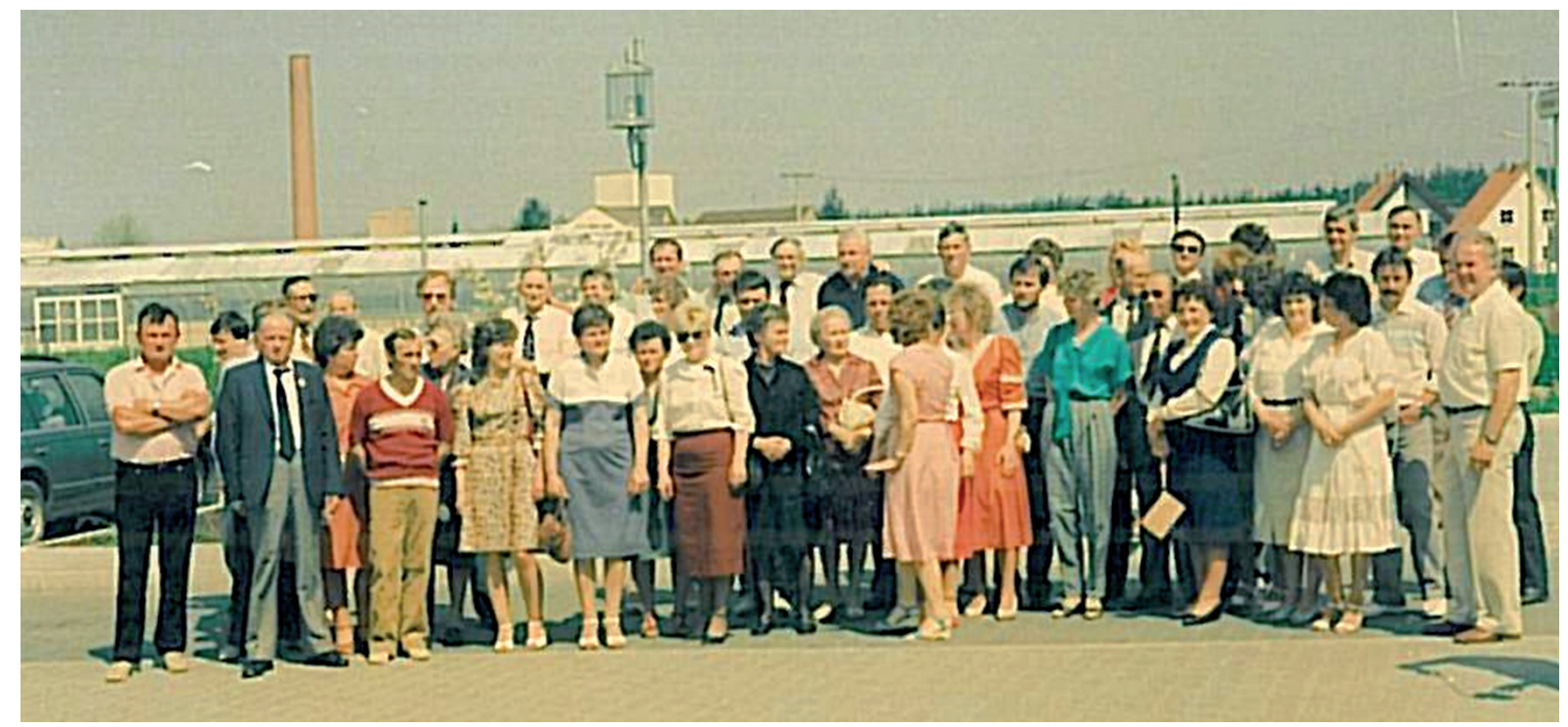

18. ábra. Rednitzhembach, Német Szövetségi Köztársaság (1986)

Én is angyalhoz mért komolysággal daráltam el mondanivalómat, és az előadás végén még egyszer meggyújtottuk a görögtüzet, mert - mi tagadás - ez tetszett a legjobban.

Utána meghatott csend. A tapsot nem ismerték akkor még Göllében, ${ }^{78}$ és csak nagynénim tapsolt, ami vidámságra fakasztotta a gyerekeket, és egy öregaszszony megjegyezte, hogy ő már ugyan sokat megért Pécsett is volt egyszer -, de el nem tudja gondolni, hogy az a pesti asszony mért csapkodta össze a tenyerét.

Ezzel zárult aztán a színdarab. A közönség kitódult az utcára, s a lámpa mindjárt vidámabban égett, pedig akkor már nem volt rá szükség. Letettem a szárnyakat, levetettem az angyali inget, és hazamentem, ahol a tenyérverdeső nagynéni jóvoltából volt minden, ami csak megterem a pesti bazárok árjegyzékében. (...)

Játékaim romjai tehát nem érdekeltek, de annál jobban vártam a másnapot. Ez a nap egyike volt azoknak a kivételes napoknak, amikor szívesen mentem iskolába, mert akkor osztották szét a „színészek” között az előadás jövedelmét. (...)

Sokáig latolgattam, hogy egy angyal föszereplö-e, és angyal kollégámmal oda döntöttünk, hogy az angyalok mindenképpen főszemélyek, tehát a mi fontosságunk se lehet kétséges.

És halálos csendben kezdődött a jutalmak kiosztása. Esküdt Lajos ${ }^{79}$ mint Szent József egy koronát kapott. Jó. Neki volt a főszerepe. Csima Ferkó negyven krajcárt. Angyaltársam harminc krajcárt. Megkapta mindenki a magáét. Rólam szó se esett. A szívem el-

78 Bánk bán 1847. október 14-én került először színre Kecskeméten, Komáromy Alajos játszhatta el Bánk bán szerepét. A mủvész 1897-ben írt visszaemlékezése: „A félszázad előtti kecskeméti Bánk-bán előadása általános tetszésben részesülhetett, mit abból következtetek, hogy volt taps elég és számomra koszorúk is."Bánk bán 19. század - Bácstudástárwww.bacstudastar.hu/bank-ban-19.szazad

79 Esküdt Lajos majdan Nagyatádi Szabó István személyi titkára lett a Földművelésügyi Minisztériumban. nehezült. Mindenki engem nézett. Ráborultam a padra, és sírtam, sírtam keservesen.

- Nem szégyelled magad? - korholt otthon édesapám.

- Elvennéd a szegény gyerekek elől a pénzt? Hát miféle gyerek vagy te? Rászorulsz te arra?

Nem tudtam válaszolni. Igazságérzetem, a felnőttek csalhatatlanságába vetett hit összedőlt bennem, könnyeim a szívemre folytak, és nem tudtam megmondani, miféle gyerek vagyok én.

Most már tudom, éppen olyan voltam, mint a többi: gyerek voltam." 80

Fekete István Kaposvárra történő beköltözése után a „színészi karrier” úgy tünik folytatódni látszott. $A z$ elemi iskola ötödik osztályát már Kaposváron kezdte el. „Fekete István egyik húga évtizedekkel később azt nyilatkozta, hogy emlékemben talán legjobban a csodálatosan szép kert maradt meg”, hozzátéve, hogy „Kaposvárott szép házat vettek a szüleim, közel a színházhoz, amit nagyon szerettünk. Egyszer ott játszottunk a színházat körülvevő parkban, késő délután, s kijött az igazgató, Mariházi, s azt kérdezte: nem akartok-e nép lenni A cigánybáróban? Pistával együtt igent mondtunk. Nekem ki kellett bontanom a varkocsomat, hogy hosszú hajjal lehessek nép. Emiatt este tíz óra után érkeztünk haza. Édesapánk a kapuban várt, zordonan azt kérdezte, hol voltatok, már úgy aggódtunk. Mire, én hetykén, mondhatnám büszkén azt feleltem: nép voltunk $A$ cigánybáróban. Talán mondanom sem kell, hogy intelmei olyan kézzel foghatóak voltak, hogy többször nem jutott eszünkbe színészi pályára lépni." ${ }^{1}$ „Évtizedek múltán Fekete István szintén Göllébe tért vissza, ha nem is színdarab, hanem egy film kapcsán az 1941 őszén forgatott és 1942 áprilisában bemutatott: „Dr. Kovács István című filmem forgatókönyvét írtam akkor, és a lakodalmi jelenet részleteire volt szükségem, amelyeket

80 Fekete I.1970: 97.- 98.

81 Sánta G. 2014: 43. 


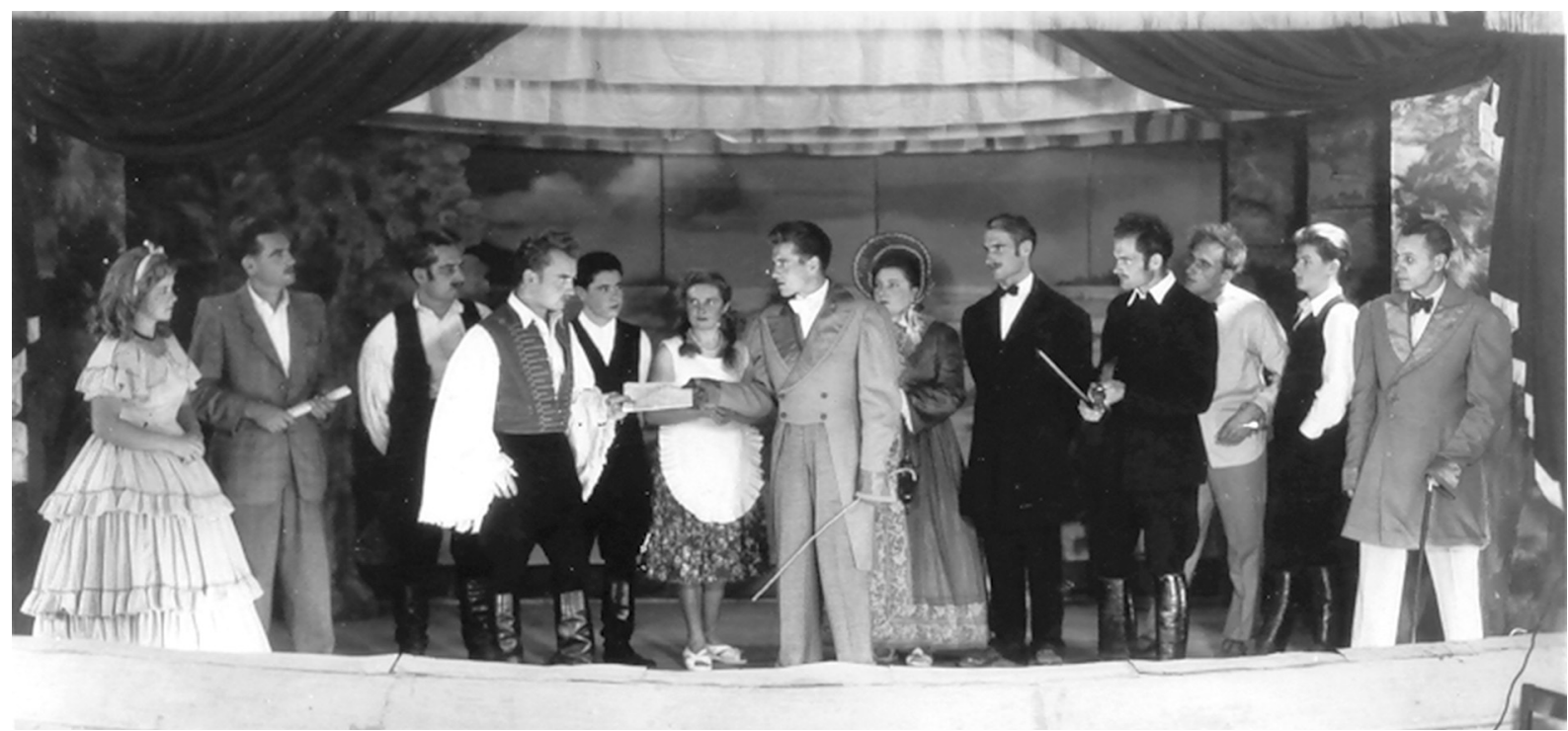

19. ábra. Dankó Pista (Gölle)

már elfelejtettem. Írtam hát Barcsának, és találkozót kértem a kaposi állomáson. (...) Ennek a filmnek egyes verses felköszöntőit - a lakodalmi jelenetnél- Barcsától kértem el, s a gölleiek sokan bekocsikáztak Dombóvárra a filmet megnézni, hiszen félig- meddig a film lakodalmában is otthon érezhették magukat. Barcsa is ott volt, és lelkesen számolt be a látottakról és Gölle büszkeségéről." ${ }^{22} A$ Dr. Kovács István címü film forgatókönyvből a göllei vőfély rigmusából, egy részlet így hangzik: „Itt van az első tál étel, behoztam, Hogy el ne ejtsem, mindig imádkoztam. Szakácsné asszonyokkal összebarátkoztam. Bors, sáfrány, gyömbérrel jól be is sózattam "83

„1934-35-ben Varga György helyettes tanító Göllében. Színdarabot tanít be, leventékkel, feldíszített kerékpárokkal versenyt rendez. 1935. április 21-én mutatják be a Tépett Rózsa címü művet." ${ }^{84}$ A kutasi születésű Pap János e művét pedig: „Először játszották 1921. november 7-én a kaposvári Városi Színházban." - olvasható a szerepkönyv borítóján.

Az 1940-es évek végén játszott színdarab a János vitéz, erről így szól a visszaemlékezés: „17 éves voltam, gazdasági iskolába jártam. ${ }^{85} \mathrm{Az}$ öreg juhász pásztor ember szűrét kértük kölcsön a darabhoz. Mindenki maga vitte a ruhát. „Hol volt maga mennyi volt a nyája mennyit loptak el? Cigányvajda nyerte el." ${ }^{86}$ Egy idősebb ember annál volt a könyv, a szöveget olvasta fel betanultuk. A fejés 6-7óra között volt, előbb fejt ${ }^{87}$ mindenki utána mentünk próbálni. Egy hónapon keresztül este mindig mentünk próbálni. Aki tervezte a színdarabot: Jól

82 Fekete I. 1970: 114

83 Fekete I. 2010: 58

84 Varga Gy. 2003: 11

85 Aranykalászos, Ezüstkalászos tanfolyamok szeptembertől májusig tartottak Göllében. Büssüi, igali, gyaláni, göllei résztvevőkkel.

86 Jellemző volt mind nő, mind férfi visszaemlékező esetén, hogy közbe-közbe szúrtak egy-egy idézetet a színdarab szövegéből, akkor is ha éppen a darabbal kapcsolatos körülményekröl beszéltek.

87 Még az 1990-es évek elején is a fejéshez igazították lakodalmakkor is a vacsora kezdés időpontját. megérted? Egyszerű parasztember, egyszerű középparaszt volt, ilyenekkel is foglalkozott. A fiatalok összementek. Bent volt kocsma, mozi helység, magasan ki volt emelve. Belépti díjat részben a kocsmárosé szedte, a mozi helyiségben rögzített székek voltak. Másik községbe nem mentünk el bemutatni a darabot."88 A Dankó Pistát 1957-58 körüli időkben vitték színre a Gölle kultúrházban (19. ábra), betanította Mezey Béla tanár, későbbiek folyamán iskolaigazgató. 1959-60 került színpadra a Mágnás Miska, és a Déryné (6-7. ábra). A Tabáni legenda, és A falurossza is belekerült a lejátszott darabok repertoárjába.

A Dankó Pista jelmezpróbájának előkészületei közben zajlott le ez a kis epizód: „Fekete parókát kapott a Berta Endre, és megkérdezte: Mi az Irén? Paróka, a cigány az fekete! Akkor nálunk szőke cigány lesz, mert ezt én fel nem veszem! A díszlet csodálatos volt. Jakab Imre népi zenekara játszott. Nagy bőröndökbe, kofferokba érkeztek a ruhák." ${ }^{89}$ Dankó Pista „A népies müzene egyetlen olyan alakja volt, akinek személyét több író és költő megörökítette. Ady Endre és Juhász Gyula verset írt hozzá, Móra Ferenc, Tömörkény István, Rákosi Viktor írásaiban is feltűnt, Gárdonyi József, Gárdonyi Géza fia, megírta Dankó regényes életrajzát. 1940-ben film is készült életéről, amelyben Jávor Pál alakította, ez volt a kétszázadik magyar hangosfilm."90

\section{Kisgyalánban színre vitt darabok}

Kisgyalánban a következő színdarabok kerültek elő az emlékezetből: természetesen mint ahogy szinte minden községben itt is A piros bugyellárissal kezdődött a felsorolás. „Helyre hozza a köszörü: gazda, szó’ ga viszonyról szól a darab. 1930-as évek végén játszották.

88 Puska Ferenc szíves közlése.

89 Kutyik Gyuláné Szalai Ildikó Gölle szíves közlése

90 Dankó Pista - Wikipédiahttps://hu.wikipedia.org/wiki/Dankó_Pista 


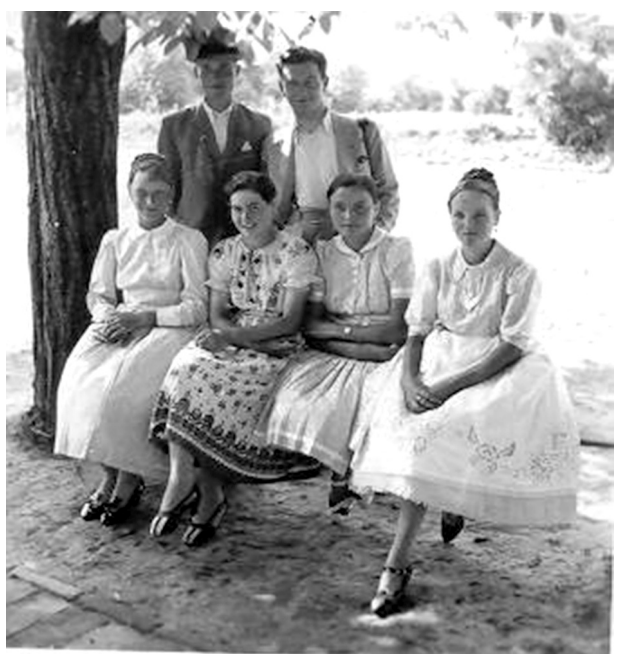

20. ábra. A fiatalok vasárnap összegyültek, „Nagylányok vasárnap délután” (Kisgyalán)

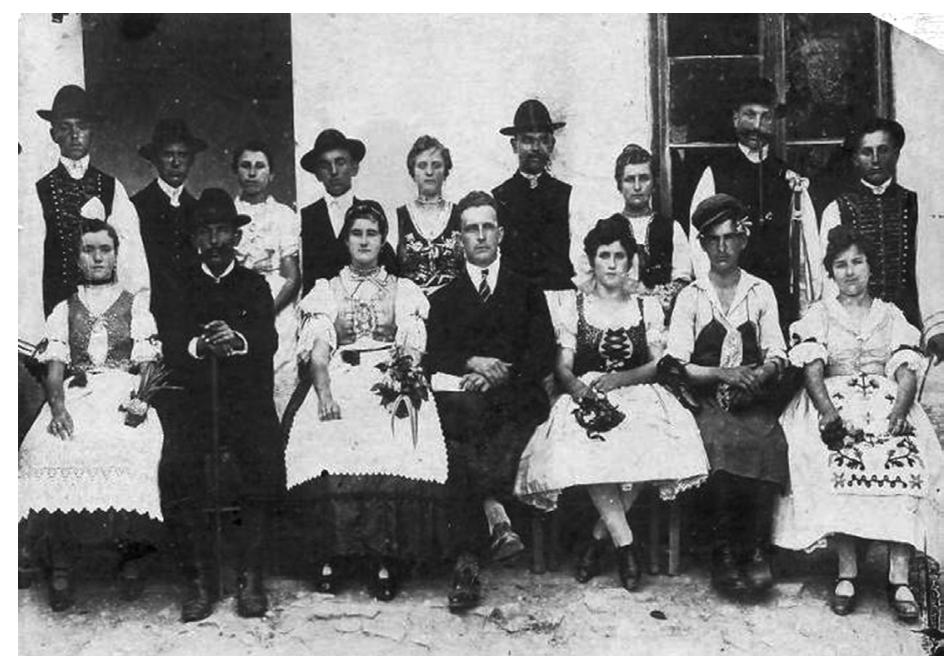

21. ábra. Színjátszó kör, Keresztes tanító úr vezetésével (Kisgyalán, 1925)
Duda Gyuri: 1940-es években játszották. Héjjas tanító tanította be, énekeltek benne.

A falu rossza, A nánai bíró lánya: 1930 körül játszották.

Karikagyűrü: Oroszok után, énekeltek benne.

Tűvé tevők: „Mi a jó, tüzes már a vasaló!” - így hangzott a felidézett mondat.

A falu rossza, Én vagyok a falu rossza címmel maradt meg a visszaemlékezésben.

Kőműves Kelemen: „A malomnál nagy mühely, meg volt csinálva. Rövid darab ezért húzták az időt, későn kezdték, de mindenki tudta, hogy azért mert rövid a darab. A tanító nem számított annyi népre. Az 1950-es években játszották." 1

„A színdarabokon kívül, tavasszal, nyáron, és kora őszi hónapokban, az összetartozást erősítő talán az egyik legszebb esemény, amit a mostani 80 év felettiek, még fiatal lányként, legényként megéltek. Minden vasárnap délután a lányok karöltve 4-5-en is, egymásba kapaszkodva az útközepén együtt vonultak végig a falun, ekkor még a forgalom nem akadályozta őket. A kezükben virágszál, az övükben csipkés zsebkendő volt tüzve, és danú'va9 ${ }^{92}$ haladtak végig a falun. A legények is öltözetesen ${ }^{93}$ csatlakoztak a lányokhoz. Csoportosan bevonultak valamelyik házhoz, s ott énekelgettek, labdáztak, beszélgettek. A most 70 év körüliek ezt még kislányként nézték végig, de ők már nem vonultak végig így a falun. Azonban ők is csinosan fel voltak öltözve a vasárnap kedvéért. A fiúk-lányok szintén összegyűltek, együtt töltötték az időt. Látható az egyik csoportképen (20. ábra), amelyen igen csinosan vannak felöltözve, a pusztai és a falusi fiatalok egyaránt. Kérdésemre, hogy „milyen esemény volt?” Természetesen így válaszoltak: „Hát vasárnap!”. Vasárnap ilyen csinosan illett öltözni.

91 Bóna Lászlóné szíves közlése.

92 Énekelve

93 Zakó, gomblyukban virág, zsebkendő kitűzve, s kalap a fejükön.
A tanítók által szervezett színjátszó körök, amiről már az 1925-ös fénykép is bizonyítékul szolgál, (21. ábra) amin Keresztes tanítót körülvevő déd avagy nagyszülők láthatóak. Az 1925-ben, az akkori 15-18 éves fiatalságról, 2003-ban is volt akit felismertünk az alapján, hogy kire hasonlít. A dédmama „nem tagadhatta volna” le a most harmincas éveiben járó dédunokáját. A fiú unokák is formítják ${ }^{94}$ nagyapjukat. A színjátszás végigkísérte az egész 20. századot. Minden tanító, tanár nevéhez füződik egy-egy betanult színdarab. Ez összefogta a fiatal, s idős korosztály egyaránt, a fiatal tanulta a szerepet, játszott, és az idős megnézte az előadásokat, s biztosította a szerepekhez szükséges ruhákat. Minden télen kellett előadást játszani, szervezni, hisz a hosszú téli estéken együtt el lehetett tölteni az időt a próbákkal.

A bor az 1980-as években került színpadra (22-23. ábra).

A 21. században is van tehetséges fiatal a faluban, aki ráadásul rímekbe is képes szedni mondandóját azonfelül, hogy egy kis helyi aktualitást is visz a darabokba, amiből aztán felismerhető a célzott személy. Bár a mai fiataloknak a száz évvel ezelőtt élt elődeikhez képest igen sok lehetőségük van szabadidejük eltöltésére, de egy kis unszolásra szakítanak időt a szereptanulásra, s a próbákra, az előadásra."95

\section{Büssüi színjátszás}

Büssüben Varga Gyula (1919-2005) színművész unokája kérésére emlékezett vissza az általa rendezett színművekre, ezt tette közkincsé Lévay Viktória szakdolgozatában. Varga Gyula Nagyberkiben született, első színjátszással kapcsolatos élményei innen származnak. „Sokoldalú társadalmi, közművelődési tevékenységet végzett, megyeszerte híres színjátszó együttest működtetett. Rövid kaposmérői tanítóskodás

94 Hasonlítanak rá.

95 Lanszkiné Széles G.: 2007: 142. 145. 

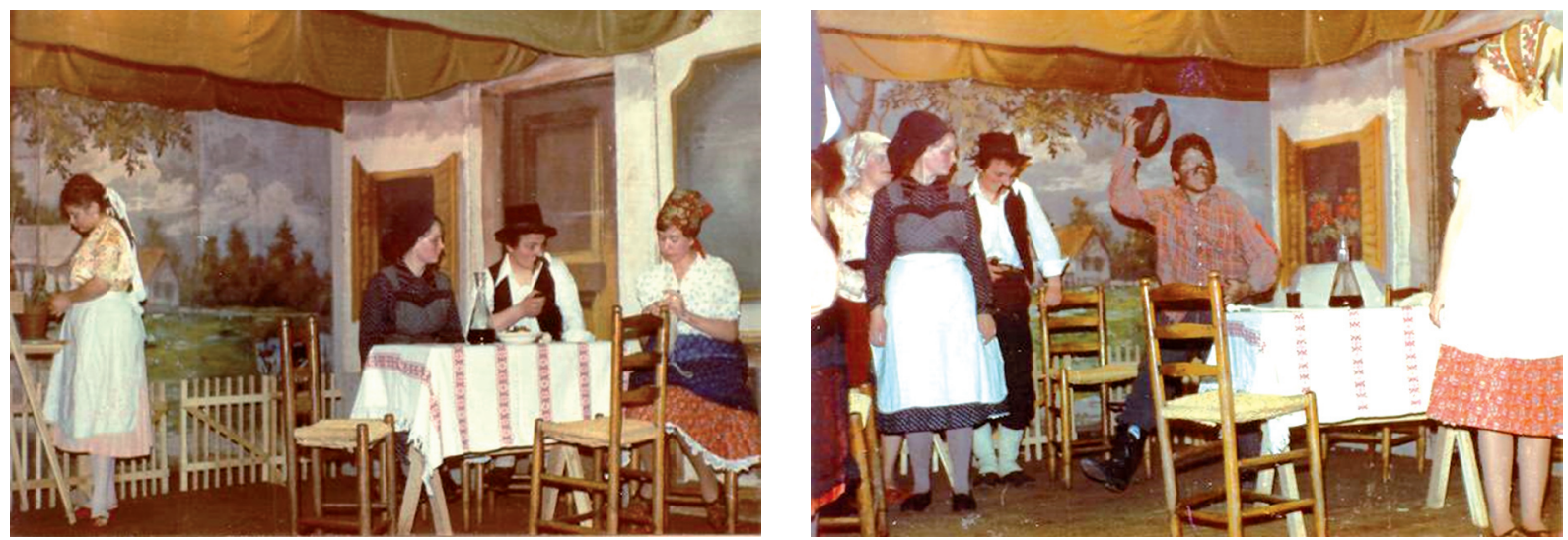

22-23. ábra. A bor címü színdarab (Kisgyalán)

után, 1957-től a tanügyigazgatásban dolgozva adta át nevelési-oktatási tapasztalatait pedagógus társainak. 1979-ben ment nyugdíjba, a megyei tanács müvelödésügyi osztályának csoportvezetőjeként. Attól kezdve összegezte kutatómunkájának eredményeit a somogyi szakfelügyelet történetéröl, melyet hét kötetben jelentetett meg."96

„Amikor először találkoztam a színházzal, úgy első-második osztályos lehettem. A szomszéd házban létesítettek egy katolikus olvasókört, ahova téli időben jártak a nagyberki parasztemberek beszélgetni, müvelődni, tulajdonképpen szórakozni. Valakinek eszébe jutott, hogy kellene a fiatalság számára egy színdarabot rendezni. A kérdés csak az volt kit lehetne megbízni ezzel az időt, türelmet, intelligenciát követelő feladattal? A tanítók nem foglalkoztak ilyesmivel, az egyik birtokot gyűjtött, a másik pedig a Hitelszövetkezetnek volt a vezetője. Tehát nem maradt idejük a gyerekekkel még külön is foglalkozni. Végül egy Király János nevü, egyébként „Makett”-nek csúfolt, igen értelmes suszter embert kértek föl, aki el is vállalta a megbízatást. (...) Egy betyártörténetet választott, Felhő Klári volt a címe. (...) Az előadás után sorsoltak egy vekkerórát. Akkoriban ez nagy dolognak számított, mert a falusi házaknál csak fali ingaórákat lehetett találni. (...)

A tanítóképző elvégzése után, 1939. szeptember 20-án, Kisasszony ünnepén mutatkoztam be a katolikus híveknek, a templomban. A plébánossal eljártunk a kukoricafosztóba, hogy megismerjenek az emberek. Október 29-én egyhangúlag megválasztottak kántortanítónak. (...) Novemberben a plébános úr levitt a legényegyletbe, akkoriban KALOT-nak hívták (...) és közölte, hogy színdarabot akar csinálni velük. (...) Nekiláttunk a Leánycsel és A részeg ember fia színpadra állításának. (...) A két előadásnak végül nem lett folytatása, mert amire belekezdtünk volna a következő darabba, behívtak katonának, és csak 1945 novemberében kerültem vissza. (...) Miután hazaérkeztünk, elkezdtem újra tanítani. Távollétemben az akkor utolsó éves Várkonyi Imre ${ }^{97}$ helyettesített.

96 VargaGyulaált. isk. tanár, tanügyi vezető - Somogy hivatalos honlapja ...www.somogy.hu/index.php?cid=3745

97 1925-ben Büssüben született földmúves szülők gyermekeként. A
(...) A következő darab Csite Károlynak a Hej, de szép a lakodalom címü színműve lett. Három darab közül választottam ki ezt, a másik szintén Csite - darab, a Gyürüs zsidó, a harmadik Illésné Ferenczy Katalin: A legnagyobb hatalom. Ezek a darabok: „Humoros, érzelgős, az egyszerủ falusi embert is megfogja a könnyen követhető, a játszók számára is reálisabb feladat. Magát a darabot Igali Pál kisbírótól kaptam."

„Ezzel kezdődött el a népszínmüvek előadásának sorozata. Ezek a darabok igénytelenek hatásvadászok volta, kevés mondanivalóval - ezt tudtam már akkor is -, de a lakosság egyszerü parasztemberekből állt, akik még felkészületlenek voltak még az igényesebb színmüvekre. (...) Közben a református lelkész, aki az ellenlábasom volt, elkezdte mondogatni a híveinek, hogy „a Varga tanító úr nem tud mást, csak ilyen tingli-tanglikat.” Ekkor néztem valami komolyabb kihívás után, természetesen nem csak a lelkész úr miatt, hanem mert akkora a szereplők is megértek bonyolultabb feladatok megoldására. A csapat összekovácsolódott, és éreztem, hogy valóban, ennél sokkal többre is képesek. Így esett a választás A hegedű című darabra. (...) A népszínmü ciklusnak tehát $A$ hegedű bemutatásával végeszakadt. Ennek legföbb oka, hogy a színjátszó csoportnak sikerült egy olyan közösséget kialakítani illetve megnyerni, akik érteni, élvezni tudták az igényesebb elöadásokat is. (...) A következő produkciónk a Huszárkisasszony címü daljáték volt. Ez nyílván újabb erőpróbát jelentett, mivel a zenés müfaj bizonyos tekintetben, de számunkra akkor min-

Bajai Tanítóképzőben 1946-ban szerzett tanítói diplomát. Először Magyaregresen, majd Csokonyavisontán dolgozott. Az ötvenes évek elején Kaposvárra került, ahol elöször tanulmányi -, majd szakfelügyelőként tevékenykedett, később iskolaigazgató lett. Munkásságának következő állomása a Tanítóképző Főiskola volt ahol először a Nyelvi és Irodalmi Tanszéket vezette, majd 1975tõl az első főigazgatója lett. A főiskola fejlődésének több állomása füződik a nevéhez: új kollégium és könyvtár építése, majd a 32 tantermes gyakorló iskola alapítása. Igényes volt saját magával és környezetével szemben. Doktori dolgozatát a megye nyelvjárási jelenségeiből írta. A Magyar Nyelvtudományi Társaság rendes tagjává választották. Mindig hü volt a szülöfalujához, Büssühöz. Gyakran írt az ott élők népdalairól, napi tevékenységükről. 1985ben vonult nyugállományba. Mozgalmas élete 1998-ban ért véget. Dr. Várkonyi Imre - Somogy Temetkezési Kft.www. somogyitemetkezes.hu/elodeink/nev-szerinti-lista/73 
denképpen, nehezebb falatnak számított. (...) Mindemellett próbálkoztunk a kabaré müfajával is. 1947-ben megjelent két országos kiadvány Vidám kabaré illetve Tarka est címen. És ezen a télen végre megtört a jég, mert már a reformátusok és a szomszéd községbeliek is eljöttek bennünket megnézni, sőt, vendégszerepelni is jártunk. Kazsokban játszottuk a Vidám kabarét és A Modern Putifárnét. (...) Ezután következett, 1949-ben a Mária főhadnagy Huszka Jenőtől, amit nem akartak engedélyezni, mondván, hogy reakciós... Am én annyira beleszerettem, hogy megváltoztattam a címet, „Szabadság szerelem"-re.

Így már nem volt politikai akadálya sem az előadás létrejöttének. Később aztán nem úsztam meg a számon kérést, valamelyik szereplő megsértődött valamiért és besúgta a pártbizottságon, hogy a Varga tanító úr mégiscsak leadta a darabot, amit a járás nem akart engedélyezni. Be is hívattak kérdőre is vontak. Azt feleltem: „Lett belőle probléma? Lett belőle valami reakció? Nem! A község lakossága szívesen fogadta, jót mulatott, a fiatalsággal újabb két hónapig foglalkoztam, kell ennél több?!

$A z$ első igényes irodalmi színmű Csiky Gergely A nagymama című írása volt a színjátszókör életében. Ezt követte aztán két további Csiky darab, a Buborékok és az Ingyenélők. A nagymama igazi erőpróbának bizonyult. Ekkor jött az emlékmü ötlete is. Amióta újraindult a színjátszás Büssüben feltett szándékom volt, hogy a jegyekből származó bevételt valamilyen nemes célra fordítsuk majd. Meg is született az elhatározás: szégyen és gyalázat, 1948-ig nem volt Büssüben a hősi hallottak emlékét megörökítő emlékmű. Így arra jutottunk a fiatalokkal, hogy a színházi rendezvényekből és egyéb gyűjtésekből állítunk egy emlékművet. 1948 júliusában el is készült és igen szép ünnepség keretében avattuk fel."

A Noszty fiú esete Tóth Marival című előadásunknál már a jelmezeket is Budapeströl hoztuk, a Bécsi utca 6 . szám alatti jelmezkölcsönzőből. Attól fogva mindig innen kölcsönöztük a szükséges ruhákat. Csütörtökön mentünk értük, pénteken volt az igazítás, szombaton a jelmezes főpróba, vasárnap pedig az előadás. Egy darabot csak kétszer játszottunk és kezdtük a következőt. Ekkortájt indították el a kulturális seregszemléket is. Az első ilyen, amin részt vettünk az igali járási verseny volt. Csehov: Háztűznéző című darabjával neveztünk be. (...)A legnagyobb sikert A kőszívű ember fiaival arattuk. Igen érdekes körülmények között jött létre. A könyvtárba érkeztek kis kiadványsorozatok, ebben a sorozatban jelent meg ez is. Nagyon megtetszett. Négy felvonás tizenkét kép... „Hej - mondom -, ha én ezt egyszer előadhatnám!" (...) Hatalmas sikere lett a bemutatónak. A föpróba után, másnap már a nagyterem sem volt elegendő, mert a környező községekből is szinte özönlöttek az emberek. $A$ járási művelődési osztály népmüvelési előadója is megnézett bennünket, utána anélkül, hogy az osztályvezető látta volna, benevezett bennünket a kulturális seregszemlére. Vasárnap újból kijött, és elmondta, hogy az osztályvezetővel együtt a következőkre jutottak: nemcsak a kultúrszemlén kell részt vennünk néhány jelenettel, hanem a verseny után elő kell adnunk az egész darabot a kaposvári Csiky Gergely színházba.
(...) Ezért aztán leveleztem a Madách Színház maszkmesterével, Ivonicza Péterrrel, hogy fogadjon engem és mutasson néhány fontosabb fogást. El is vállalta. Valamelyik nap aztán jól felpakoltam az előző heti disznótorosokból, összegyüjtöttünk egy jókora csomagra valót és azzal állítottam be hozzá. Nagyon kedvesen fogadott, amikor pedig meglátta a hatalmas kosarat- mert akkoriban azokban az ínséges időkben nagy dolog volt az a sok hurka, kolbász, sonka, - azt sem tudta mit csináljon örömében. Mindent az égvilágon elmondott, megmutatott a segédje arcán. Hogyan kell hajat őszíteni, az arcot nagy fényben, vagy sötétben sminkelni, öregíteni, hogyan kell ráncokat rajzolni, kiemelni a szemet egy fiatalnak vagy egy lánynak. (...) Végül elérkezett a nagy nap: 1955. április 17-én, (...) délután fél négykor pedig kezdődött a várva várt előadás a „SZÍNHÁZBAN”! (...) Nyílt színi tapsok kísérték az egyes jeleneteket. A négy felvonás azonban sokáig tartott, s az esti előadás miatt a zárójelenet előtt az ügyelő le akarta engedni a függönyt. Ehhez azonban a közönségnek is és a mi színpadmesterünknek is volt néhány szava: a nézők füttyültek, nem akarták elhagyni a nézőteret, a színpadmester pedig fogott egy lapátot, és azzal állt a megriadt ügyelő és a függönyzsinór közé (...) a szereplők jutalma az volt, hogy megnézhették az esti színházi előadás, „A szép juhásznét”. (...)

„A büssüi színjátszókör igen termékeny és sikeres tíz esztendejét $A z$ aranyember győzelme a megyei kulturális szemlén méltóképp zárta le. (...) Egyszóval mindenkinek, szereplőknek és a közönségnek egyaránt szívügyévé vált a színjátszó csoport sorsa. A járási megyei elismerések szintén sokat jelentettek mindanynyiunk számára. A sikeren és a szórakozáson túl nagy jelentősége volt ennek a tíz esztendőnek, mert a közös munka, küzdelem, maga a színjátszás, a mások börébe való belebújás és minden egyéb, ami a színházasdi velejárója, hatalmas szellemi fejlődést idézett elő az arra fogékonyakban." 98

1956. július 26-án búcsúztatták el Büssüben Varga Gyulát, Kaposmérőben folytatta a színdarabok rendezését, Kaposváron a Kaposvári Járási Művelődési osztályon dolgozott ezentúl. A 24-29. ábrákon büssüi színjátszók láthatóak.

Varga Gyula indította el a büssüi férfikart is útjára. „Kirobbanó sikereket értek el az akkori idők járási kulturális rendezvényein, ifjúsági seregszemléin. Színjátszó és énekkari kultúrájuk ismerté tette községük nevét megyeszerte." 99 Varga Gyulát énekkari munkájában Zimre József követte. Itt vissza is kanyarodtunk Fonóhoz, Kisgyalánhoz, mert ez a kórus volt a megalapozója a majdani 1994-ben arany minősítést haza hozó a Kisgyaláni Férfikarnak. A szálak összefonódnak mindenhol, az utalások kapcsán is láthatjuk, a vidék ugyanúgy beletartozik az ország vérkeringésébe, értékes eredmények elérésére képes, még akkor is ha csak saját maga szórakoztatására kezdett bele egy-egy színdarabba, vagy egy énekkari próbába.

98 Lévay V. 1998: 19. 6. 16. 27.

99 A Kisgyaláni Mezőgazdasági Termelőszövetkezet férfikarának rövid története 1940-1985. 

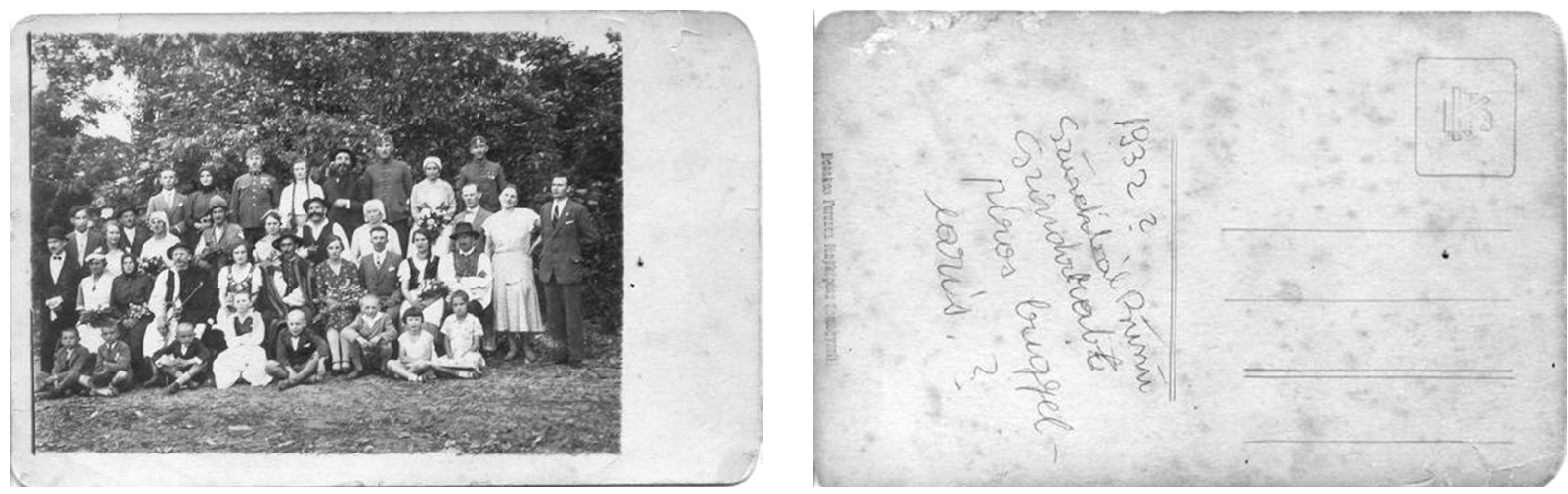

24-25. ábra. Kérdőjellel: A piros bugyelláris (Büssü, 1932?)
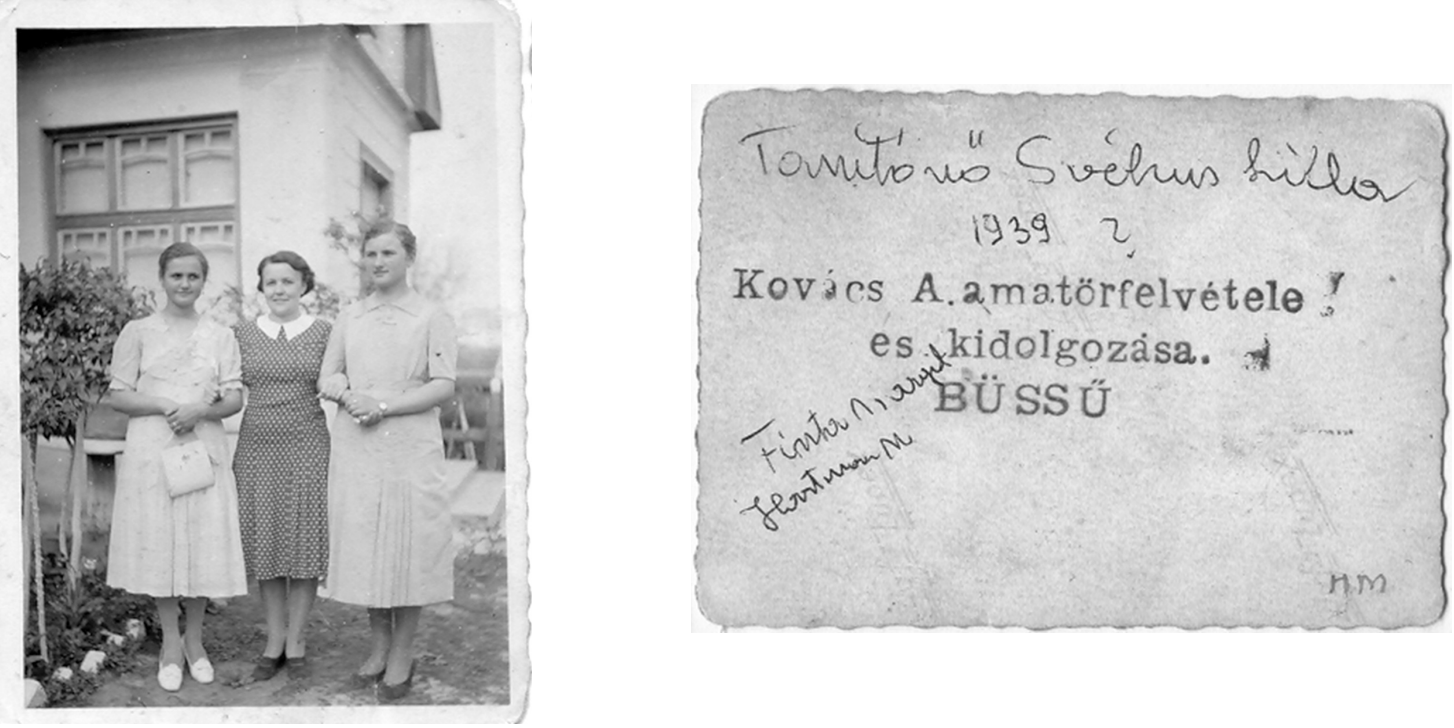

26-27. ábra. Tanítónő (Büssü)
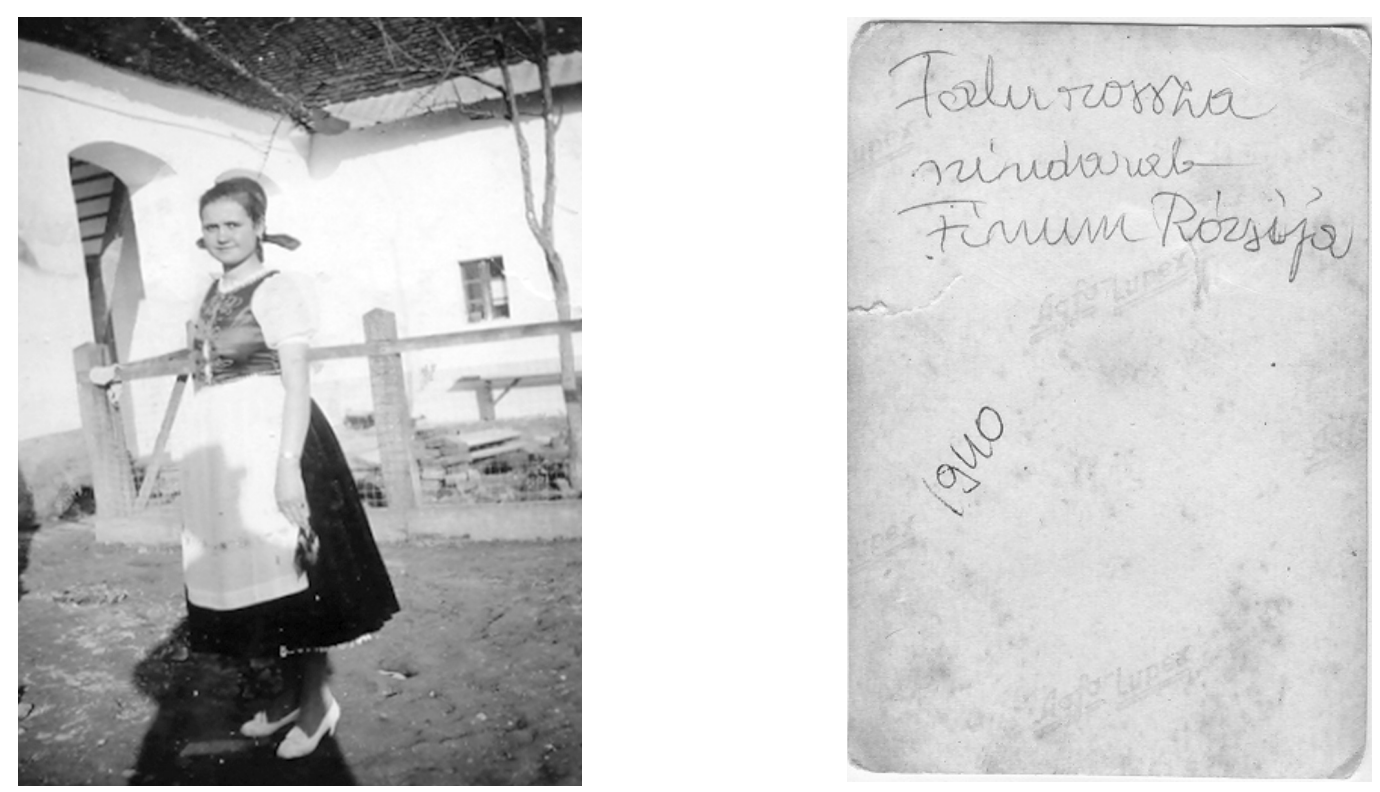

28-29. ábra. A falu rossza szereplő: Hartmann Mária színdarab Büssü (1940) 
Ha, a kitüzött cél mindig egy kicsivel több, mindig előrébb lép az ember. Kitűnő bizonyíték erre Somogyjád példája is:

„1967. február 19. nevezetes nap Somogyjád történetében. Ezen a napon országos hírű kulturális irodalmi bemutatót tartott az irodalmi színpad. A korszak legnevesebb és legnagyobb tiszteletnek örvendő költőjének, Illyés Gyulának „Az éden elvesztése” című verses oratóriumát adták ellő óriási sikerrel. A korabeli beszámolók szerint a zsúfolásig megtelt Kultúrotthon nagytermében mintegy 350 néző élvezte az előadást. A példátlan érdeklődés annak is köszönhető volt, hogy a költő is jelen volt, feleségével együtt az oratórium bemutatóján. Két neves somogyi költő Takács Gyula és Sipos Gyula ugyancsak jelen voltak a nagy eseményen. A rendkívüli előadás legalább is egy község kulturális életét tekintve, szokatlan előzmények után jött létre. Stamler Imre, az irodalmi színpad vezetője és Tokaji Lajos tanár, a kultúrotthon igazgatója 1966. augusztus 26-án kelt levelükben azzal a kéréssel fordultak Illyéshez, hogy írjon az irodalmi színpad részére egy új mủvet. A mủalkotás tartalmával kapcsolatban így fogalmazták meg kérésüket. „Szeretnénk, ha az idén irodalmi müsorunk az atomról szólna. Szeretnénk kifejezni, hatásosan megérteni, megéreztetni mindazt, ami az atomból: korunk meghatározójából az élet nagy lehetőségéből vagy a halál fagyosságát hordozó hatalomból az emberiségre várhat... (...) Illyés Gyula 1967-ben kelt naplójegyzeteiben olvasható a budapesti előadás előtt elmondott bevezetője, melyben egyebek közt arról beszélt, hogy milyen művészi megfontolásból alkotta meg oratóriumát: „Mikor én Somogyjádról megkaptam ezt a kedves, először naivnak tetsző felszólítást, úgy éreztem, hogy ez az a pillanat amikor nekem engedelmeskednem kell, és amúgy is már régebbi idevágó gondolataimat valami formába öntenem. Fölmerült az, hogy most népszerüen, az úgynevezett falusi nívón? Ez megalázott volna engem is és őket is. Látták az eddigi előadásokban, hogy ha próbaként egy kicsit megnézzük, milyen elemek vannak a magyar vidéken, hát igen nívós és igen kitűnő szellem uralkodik ott. Azt tökéltem el magamban, ha megírom ezt a bölcseleti költeményt, olyan nívón írom meg, mint hogyha legmagasabb európai fórum elé kerülne, mintha mondjuk, a francia akadémián már szürrealista barátaim ülnének, és ők tiszteltek volna meg ezzel a felszólítással. ${ }^{100}$

„Az éden elvesztése a honi irodalmi elit érdeklődését is felkeltette. Déry Tibor Szembenézni címmel válaszdarabot írt, melyben borúlátóbban ítélte meg az atomháborús fenyegetettségben élő emberiség jövőjét, mint Illyés. Déry művét 1967 decemberében közölte az Új Írás, míg a Somogyjádi Irodalmi Színpad 1970. június 7-én mutatta be - az előadáson megjelent az író is. ${ }^{101}$ Illyés Gyula ugyanolyan színvonalú darabbal tisztelte meg a Somogyjádiakat „mintha mondjuk a francia akadémián már szürrealista barátaim ülnének,” nem tett különbséget.

100 Kiss N. P. Polgár T. Szántó L. 2009: 182., 183.

101 Szenzáció lett Illyés atomról írt darabjának jádi bemutatója ... www.sonline.hu , Somogy > Kultúra
Somogyjádon ötévente bemutatják $\mathrm{Az}$ éden elvesztését. Somogyjádon megalapozott hagyománya maradt a színjátszásnak.

Fonó, Kisgyalán, Gölle, Büssü, színjátszása jelen években néhány főként gyerekek által előadott darabokból áll. Az ezredforduló utáni években Dömötör Tekla által fél évszázada átélt népdaléneklés a fonóban, ma újraéled Fonóban is: „llyen fonóban jártunk 1959-ben például Túrán, ahol a nagylányok egy özvegyasszony házában, az ő felügyelete mellett kézimunkázgattak a télen át; meghatározott napokon azután a fiuk látogatták meg a "fonót” s a népdaléneklésnek, játékoknak se vége, se hossza nem volt." Községeinkben asszonykórusokat alapítottak, akik többszörönként meghívják egymást, és előadásokat tartanak. Az idősebb generáció tagjait is segítségül kérik azáltal, hogy az általuk elénekelt régi népdalokat lejegyzik. A balladás könyvek régebbi kiadványaiból megkérik a legidősebbeket, hogy énekeljék el amit ismernek, - már pedig sokat ismernek! - és így bekerülnek az újként énekeltek közé, ezek a balladák is. Az 1990-es évek végéről maradt fent színfoltként az a történet mikor Major Jóska bácsi és Nagy Pali bácsi Kisgyalánba leült a buszmegállóba, és hosszan népballadákat énekeltek.

Ugyanígy Fonóban Bodó Istvánt (népi fafaragó 1916) nagyon szép hangjának köszönhetően, a tsz. kirándulások alkalmával szinte kötelezően felkérték, hogy a buszban énekelje el a Szendre báró leánya címü népballadát. Az 1970-es években még az magától értetendő volt, hogy eredeti, nem feldogozott teljes balladát énekel valaki közkívánatra társai számára! A buszsoförök ekkor még nem rádiót, magnót, CD.-t kapcsoltak be, hanem a mikrofont adták az énekelni vágyó kezébe.

A tartalmas szórakozás lehetősége biztosítva volt, és van ma is. Ezért fontos feladat, hogy az ezredfordulón túl is lejegyezzük mikor és hol milyen előadások születtek.

\section{Köszönetnyilvánítás}

Köszönetet mondok Varga Róbert nyugalmazott könyvtárigazgatónak, aki számos szakirodalom rendelkezésemre bocsájtásával segített színvonalasabbá tenni a tanulmányomat. Hálás köszönetemet fejezem ki Dr. Knézy Juditnak és Prof. Dr. Rosta Istvánnak a kéziratom megtisztelő lektorálásáért. 


\section{Irodalom}

DöмöтöR T. 1960: A színjátszás funkciója falun. Színházi tanulmányok. Színháztudományi Intézet, Budapest.

DöмÖтöR T. 1983: Naptári ünnepek, népi színjátszás. Akadémiai Kiadó, Budapest.

FEKETE I. 1970: Öszi vásár. Móra Ferenc Könyvkiadó, Budapest.

FEKETE I. 1970: Ballagó idő Budapest, Móra kiadó.

FEKETE I. 2010: Dr. Kovács István filmforgatókönyv. Fekete István Irodalmi Társaság, Ajka. Frech J.2013: Mosdós Magánkiadás

G. JÁGER M. 2001: Mesztegnyő. Budapest.

Kelemen A.1938: Szűz Mária koronája színmü 4 felvonásban. Somogy megyei nyomda RT. Kaposvár.

KIss N. P., PolgÁR T. és SzÁNTó L. 2009: Somogyjád

LANSZKINÉ SzÉLES G. 2007: Kisgyalán története és néprajza. Kisgyalán Községi Önkormányzat, Kaposvár.
LANSZKINÉ SZÉLES G. 2013: Fonó története és néprajza. Fonó Községi Önkormányzat, Kaposvár.

LANSZKINÉ SzÉLES G. 2011: Falucsúfolók, szállóigék és a falvak egymás közti divatja. Act Sci Soc: 181-196

LÉVAY V. 1998: „A lámpás” Szakdolgozat Színház és Filmművészeti Főiskola. Budapest. Sánta G. 2014: Fekete István nyomában. Móra kiadó, Budapest.

SzÁNTÓ I.1956. április 6.: Az aranyember Büssün. Somogyi Néplap.

PusKÁs B. 2004: Kaposfüred. Pető és Társa Nyomdaipari BT. Kaposvár

VARGA É. 1992: „A cseperkekalap” K. Pap János színművei Somogyi Múzeumok Közleményei 9: 233-248.

VARGA GY. 2003: Csékúti emlékkönyv Veszprém Kiadja: Varga György és Varga Tamás

Virág É. 1988: Egy tanító helye és szerepe faluja életében. Kaposvári Tanítóképző Főiskola Szakdolgozat. 
